\title{
REVIEW
}

\section{The pathology of malabsorption: current concepts}

\author{
S R Owens \& J K Greenson ${ }^{1}$ \\ Departments of Pathology, University of Pittsburgh Medical Center, Pittsburgh, PA and ${ }^{1}$ University of Michigan Health \\ System, Ann Arbor, MI, USA
}

Owens S R \& Greenson J K

(2007) Histopathology 50, 64-82

The pathology of malabsorption: current concepts

Intestinal malabsorption results from a wide variety of causes, which can most easily be organized into three groups. Maldigestion arises from problems with mixing or with digestive mediators, and includes postgastrectomy patients and those with deficiencies of pancreatic or intestinal enzymes, or of bile salts. Mucosal and mural causes of malabsorption are abundant, and include gluten-sensitive enteropathy, tropical sprue, autoimmune enteropathy, and HIV/ AIDS-related enteropathy, as well as mural conditions such as systemic sclerosis. Finally, microbial causes of malabsorption include bacterial overgrowth, Whipple's disease, and numerous infections or infestations that are most frequently seen in immunocompromised patients. An overview of the most common and interesting entities in each of these categories follows, along with a discussion of current concepts. Mucosal conditions and microbial causes of malabsorption are given special attention.

Keywords: autoimmune enteropathy, bacterial overgrowth, coeliac disease, giardiasis, gluten-sensitive enteropathy, malabsorption, sprue, Whipple's disease

Abbreviations: AE, autoimmune enteropathy; CD, Crohn's disease; DH, dermatitis herpetiformis; EATCL, enteropathy associated T-cell lymphoma; ELISA, enzyme-linked immunosorbent assay; EM, electron microscopy; GFD, gluten-free diet; GSE, gluten-sensitive enteropathy; H\&E, haematoxylin and eosin; HIV/AIDS, human immunodeficiency virus/acquired immunodeficiency syndrome; IBD, inflammatory bowel disease; IEL, intraepithelial lymphocyte(s); NSAIDS, non-steroidal anti-inflammatory drugs; PIL, primary lymphangectasia; SI, small intestine; TPN, total parenteral nutrition; TS, tropical sprue; TTG, tissue transglutaminase; UC, ulcerative colitis; WD, Whipple's disease

\section{Introduction}

The human gastrointestinal (GI) tract is the site of absorption of a wide variety of ingested nutrients, including vitamins, proteins, carbohydrates and fats. Much of this absorption occurs in the small intestine (SI), where the high surface area provided by the villous and microvillous architecture optimizes uptake of dietary substances. The specialized SI mucosa

Address for correspondence: Joel K Greenson MD, Professor of Pathology, University of Michigan Medical School, Rm 2G332, Box 0054, 1500 E. Medical Center Drive, Ann Arbor, MI 48109-0054, USA. e-mail: facjkgmd@umich.edu contains numerous digestive enzymes on its surface, as well as an intricate network of lymphatics and blood vessels providing access to the bloodstream. Adequate digestion and absorption depend on a multitude of factors, including mechanical mixing, enzyme production and activity, proper mucosal function, adequate blood supply, intestinal motility and even normal microbial ecology.

Accordingly, malfunctions in any of these components can lead to failure to absorb nutrients from the diet, often resulting in some combination of diarrhoea, steatorrhoea, malnutrition, weight loss and anaemia. The resultant symptoms are known as the malabsorption syndrome(s), which can be grouped by 
their aetiology into three broad categories. Thus, malabsorption may result from maldigestion, such as occurs in inadequate mixing (e.g. after gastrectomy) or in enzyme or bile salt deficiencies, from mucosal or mural problems, such as various enteropathies or neuromuscular conditions, or from microbial causes, such as bacterial overgrowth and various infections/ infestations.

The vast number of causes of intestinal malabsorption precludes an exhaustive review. Therefore, we will attempt an overview of the most common and interesting aetiologies in the three categories, with a more complete discussion of a handful of entities in each, along with a review of current concepts. Special emphasis will be afforded to mucosal problems, as well as to several microbial conditions.

\section{Maldigestion}

\section{INADEQUATE MIXING}

A full discussion of the mechanics of digestion is beyond the scope of this review. Early digestion relies on the mechanical disruption of ingested food by chewing as well as mixing with initial digestive enzymes such as amylase in the saliva. Once the food bolus is in the stomach, further mechanical disruption occurs as the viscus churns the semiliquid ingestate. Proper digestion relies on the appropriate transmission of the disaggregated, liquefied food ('chyme') to the duodenum via the pyloric sphincter. The adequate mixing of chyme with bile salts and pancreatic enzymes, as well as its exposure to endogenous intestinal enzymes on the mucosal surface, depends on its piecemeal delivery to the duodenum in a controlled fashion. ${ }^{1,2}$

Several difficulties may arise with the loss of proper gastric function, as in patients who have undergone total or partial gastrectomy, or who have had a suboptimal result from other surgical procedures such as Nissen fundoplication or bariatric surgery. ${ }^{3-11}$ The functional or structural loss of the gastric reservoir leads to rapid transit of large quantities of inadequately mixed, osmotically active food into the small bowel. As a result, mixing of bile salts and pancreatic enzymes with the ingestate is inadequate. The resultant osmotic pressure can lead to large fluid shifts, increasing the liquid bulk of the digestive stream. ${ }^{12,13}$ The rapid transit of partially digested food through the tract results in explosive diarrhoea and, possibly, malabsorption of nutrients. ${ }^{13,14}$ Additionally, the passage of substantially intact liquid and solid food into the small bowel may result in disruptions of the normal intestinal microbial ecology, the results of which are discussed below.

INSUFFICIENCY OF DIGESTIVE MEDIATORS

As suggested above, numerous digestive mediators are necessary for proper digestion and absorption of nutrients. Bile salts from the liver emulsify fats, opening them to lipolytic enzymes and ultimately allowing the absorption of lipids and of lipid-soluble nutrients. Proper enzymatic activity is essential, serving chemically to alter the nutrients for uptake by the intestine. Pancreatic enzymes such as amylase, lipase, trypsin and chymotrypsin act in concert with enzymes intrinsic to the intestinal mucosa, including lactase, maltase, sucrase and numerous others, resulting in the chemical modification of proteins, complex carbohydrates, lipids and disaccharides. Each of these components is a potential site of disruption of proper digestion and can result in malabsorption of nutrients.

Accordingly, a defect or deficiency in any of these constituents may lead to maldigestion and malabsorption. Abnormal liver function may cause a decrease in bile salt production. Structural abnormalities in the biliary system may lead to a decrease in delivery of bile salts to the digestive stream. Examples of such conditions are gallstone disease, inflammatory conditions such as primary sclerosing cholangitis, and congenital anomalies such as biliary atresia.

The myriad of enzymes involved in digestion provide ample sites for malfunction. The exocrine pancreas secretes proteolytic and lipolytic enzymes (particularly trypsin and lipase) crucial to proper digestion. Conditions such as chronic pancreatitis, commonly from alcohol abuse or chronic biliary obstruction, and autoimmune pancreatitis may lead to a reduction in exocrine pancreatic mass and a resultant decrease in enzyme production. ${ }^{14}$ Similarly, surgical resection of sizeable quantities of pancreatic tissue can cause such insufficiency. Clinically significant steatorrhoea and weight loss usually do not occur unless there is a considerable reduction in enzyme secretion (>90\%). ${ }^{15,16}$ Congenital conditions such as cystic fibrosis may lead to exocrine pancreatic insufficiency by preventing the outflow of enzymes via mucus plugging. ${ }^{15,17-19}$

The small intestinal mucosa contains many intrinsic digestive enzymes, particularly those involved in carbohydrate digestion. Deficiencies have been described in many mucosal disaccharidases. ${ }^{20}$ However, lactase deficiency ('hypolactasia') is by far the most common. In fact, adult-onset (primary) hypolactasia is present in 
the majority of the world's population. ${ }^{21}$ Lactase is a disaccharidase present on the surface of microvilli, which enzymatically cleaves lactose into its constituent sugars, glucose and galactose. Normally, lactase levels are down-regulated in early childhood, corresponding with weaning. This process varies in its completeness, and some people are left with nearly absent lactase activity. Thus, lactase 'deficiency' is a result of decreased enzyme synthesis rather than of an enzyme defect. ${ }^{22-24}$ Symptomatic hypolactasia results from the fermentation of unmodified lactose by intestinal flora, mostly in the large intestine, resulting in the production of large quantities of gas with ensuing abdominal discomfort. The intact, osmotically active disaccharide can lead to intestinal hypermotility and diarrhoea. ${ }^{25}$ Finally, changes in the luminal milieu may result in bacterial overgrowth, discussed below.

Histologically, intestinal mucosa from a lactosedeficient patient is normal. Immunohistochemistry performed on such a biopsy will show a patchy distribution of lactase on the surface of the villi, whereas the normal pattern is diffuse. ${ }^{26}$ While the diagnosis is usually made clinically, the administration of a 'lactose challenge' and the measurement of breath hydrogen levels can help. Lactose (or lactulose) is administered to the patient orally. In patients with lactase deficiency, fermentation of the intact disaccharide by intestinal flora produces large quantities of hydrogen, which may be measured in the exhaled breath. ${ }^{21}$

Rarely, a primary lactase deficiency is seen congenitally in infants. Primary deficiencies in other disaccharidases are also well known, including deficiencies in sucrase and trehalase. ${ }^{20}$ Finally, secondary enzyme deficiencies may result from conditions causing widespread mucosal injury, such as gluten-sensitive enteropathy, tropical sprue and inflammatory bowel disease (IBD). These entities are discussed below.

\section{Mucosal and mural problems}

DECREASED MUCOSA

Numerous conditions can cause a decrease in the amount of mucosal mass in the small intestine. Such a situation results in decreased absorptive surface area, a decreased transit time and relative lack of exposure to the aforementioned intestinal enzymes, all of which may lead to malabsorption. The loss of mucosa may be absolute, as in patients who have undergone a partial small bowel resection or who have mucosal damage due to disease, or functional, as in patients with a bypassed or 'blind' loop caused by entero-enteric or entero-colic fistula, for example. ${ }^{27}$

\section{MUCOSAL DISEASE}

Many of the entities commonly associated with malabsorption syndromes fall into this category. These diseases may cause malabsorption through a variety of mechanisms discussed here, especially via an absolute or functional loss of mucosal surface area. Glutensensitive enteropathy, tropical sprue, autoimmune enteropathy and intestinal lymphangiectasia will be discussed in detail.

\section{Gluten-sensitive enteropathy}

Also known as coeliac sprue, coeliac disease, nontropical sprue and gluten-induced enteropathy, glutensensitive enteropathy (GSE) affects as many as one in every 120-300 people in Europe and North America, ${ }^{28}$ where its prevalence is highest. It is generally rare in persons of Asian descent and in Caribbean peoples of African background, but is also found in parts of India. The condition results from an inappropriate cell-mediated immune response to an ingested protein (gluten), found in wheat, barley, and rye. GSE patients learn that gluten may be found in a wide variety of seemingly unexpected places, such as medications, processed foods, emulsifiers and beers. ${ }^{28,29}$

The diagnosis of GSE relies on clinicopathological studies including mucosal biopsy, serological studies and the effects of a diet free of gluten on the patient's symptoms. ${ }^{30-32}$ Children with GSE usually present with symptoms of diarrhoea, impaired growth and abdominal discomfort within the first 24 months of life, gradually worsening with the introduction of cereals to the diet. $^{28,29,32-34}$ Young patients may also manifest vomiting and pallor. If undiagnosed, GSE can lead to permanent short stature and pubertal delay, as well as the sequelae of nutrient deficiency such as iron deficiency or megaloblastic anaemia and rickets. Patients presenting as adults may have short stature and/or historical symptoms indicative of ongoing disease since childhood. ${ }^{28,32,35}$ However, GSE can also develop primarily in adulthood. ${ }^{28,36,37}$ As many as half of adult patients may be relatively asymptomatic, without significant diarrhoea. ${ }^{28,29,36,37}$ Therefore, the diagnosis must be considered in the setting of unexplained iron-deficiency anaemia, which is currently the most common clinical presentation of GSE in adults. ${ }^{28,36}$ Patients may also present with megaloblastic anaemia from folate malabsorption, hypocalcaemia from vitamin D deficiency, or coagulopathy from vitamin K deficiency. ${ }^{28,29,32,36,37}$

Mucosal biopsy of the duodenum or jejunum is still the best diagnostic tool for GSE, confirming serological and other clinical findings. ${ }^{28,37}$ The normal duodenal 

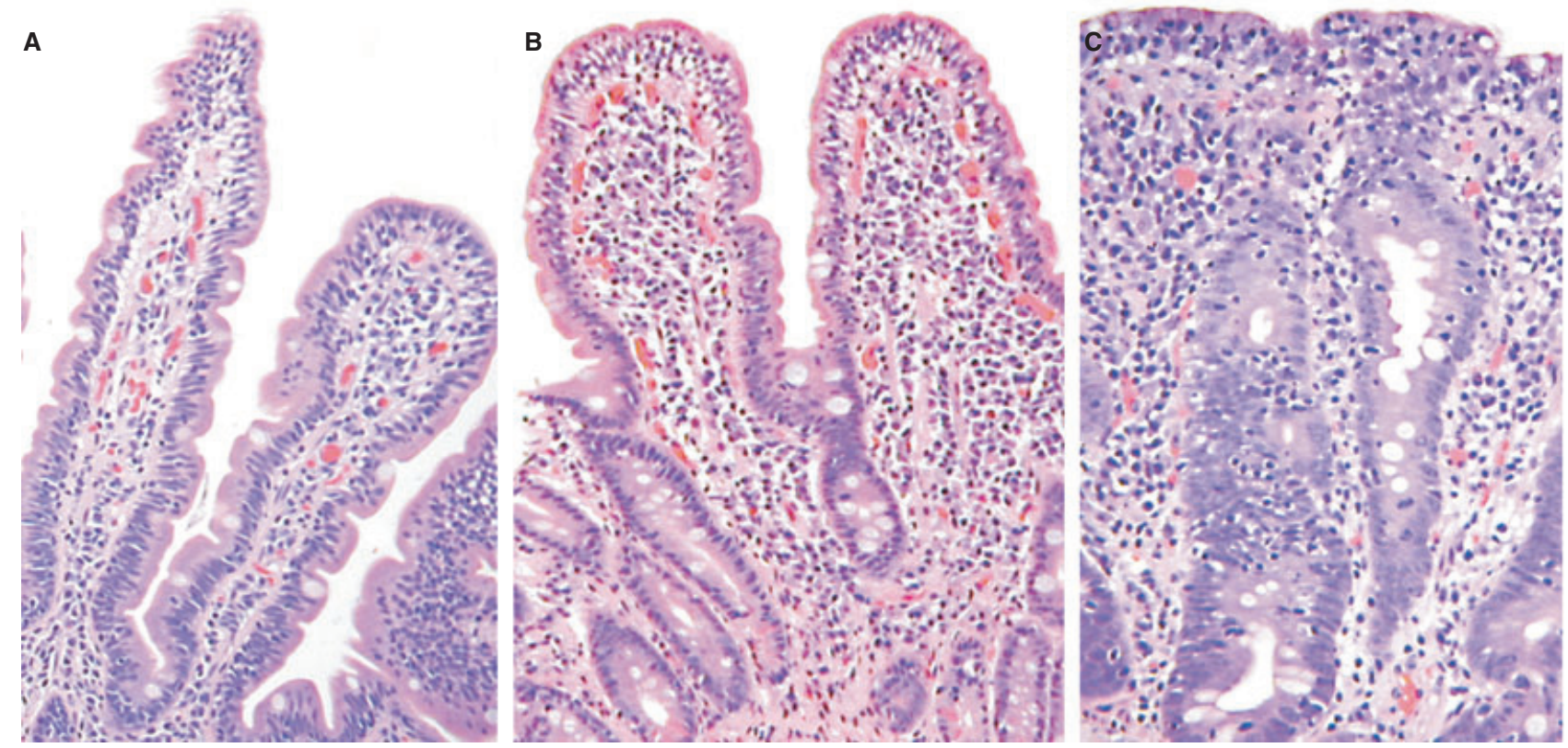

Figure 1. Coeliac disease composite showing Marsh 1, 2 and 3 lesions. A, Marsh 1. Normal villous architecture with increased intraepithelial lymphocytes. B, Marsh 2. Moderate villous blunting with increased intraepithelial lymphocytes. C, Marsh 3. Complete villous atrophy with crypt hyperplasia and increased intraepithelial lymphocytes.

mucosa has long, slender villi, with a length approximately three times the depth of the corresponding crypts. While some advocate orientation of the biopsy specimen using a dissecting microscope, we have found this to be unnecessary in routine practice. Normally, a small number of $\mathrm{T}$ lymphocytes inhabit the mucosal epithelium itself [intraepithelial lymphocytes (IELs)]. For every 100 enterocytes, there are $<40$ lymphocytes under ordinary conditions, or $<12$ lymphocytes at the tip of each villus. ${ }^{29,38-42}$

Histologic evidence of GSE depends on abnormalities in either architecture (villous blunting) or the number of IELs, or both. ${ }^{30,37,43,44}$ Classically, GSE results in villous blunting consisting of short, widened villi or even totally flat intestinal mucosa. This is accompanied by so-called 'crypt hyperplasia', where the crypt depth increases with an attendant increase in enterocyte turnover, resulting in what are termed 'high-riding' mitotic figures near the mucosal surface. The overall thickness of the mucosa remains relatively unchanged, but the villus:crypt ratio, normally $>2: 1$ or $3: 1$, decreases as the villi become blunted. Partially absorbed lipid may be seen as tiny clear droplets in the enterocytes, known as 'lipid hang-up'. These architectural changes are accompanied or preceded by an increase in the number of IELs over the normal numbers cited above, corresponding to the cellmediated immune nature of the disorder. ${ }^{39-42}$ These are largely (> 95\%) CD3 + T cells, with a relatively high proportion of the $\gamma \delta$ subtype. ${ }^{31,38}$ In some cases, the mucosal architecture may be relatively or completely normal, with only an increase in IELs evident. Seen often in the early phase of disease, this change may be quite subtle and should be actively sought in biopsies where GSE is in the clinical differential diagnosis. ${ }^{39,40,45}$ The most well-known classification scheme for the histological findings of GSE is the Marsh Classification (Figures 1 and 2). ${ }^{45,46}$

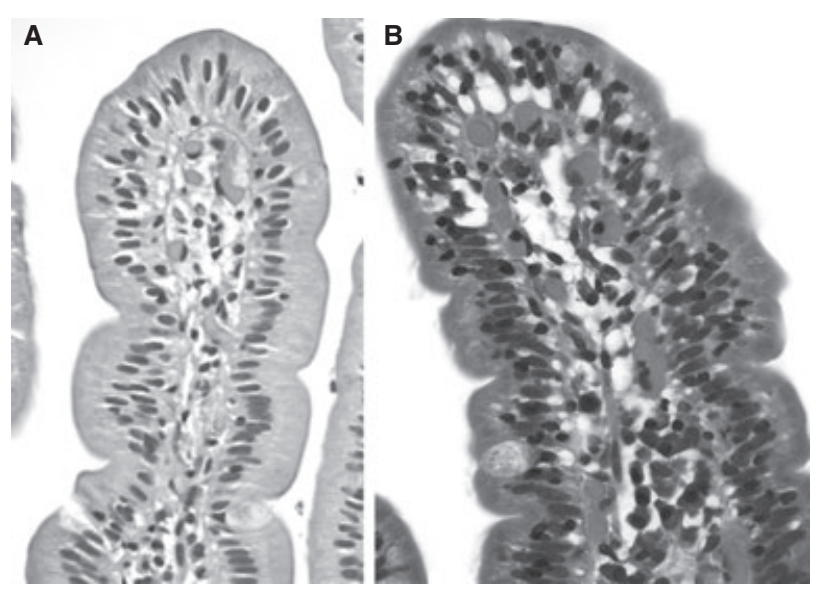

Figure 2. A, Normal villus with very few intraepithelial lymphocytes. B, Marsh 1 lesion with increased intraepithelial lymphocytes. 
The changes of GSE are usually most prominent in the biopsy specimens from the proximal small bowel, making duodenal biopsy sufficient for examination; the distal duodenum is preferred in order to avoid biopsy of the duodenal bulb, which is often architecturally altered by peptic influence from the stomach. ${ }^{28,29,47}$ However, the alterations may be seen all the way to the distal ileum. Often, the more proximal small bowel will have full-blown sprue-like changes while the distal bowel has only an increase in IELs. ${ }^{43,44,47}$ Also, GSE patients may manifest an increase in IELs outside the small intestine, including the stomach ('lymphocytic gastritis') and the colorectum. ${ }^{48-50}$

It should be noted that while these mucosal alterations are classically associated with GSE, they are strictly non-specific and may be seen in a variety of conditions leading to mucosal injury, some of which are discussed below. Several conditions have been shown to be associated with increased duodenal IELs, including Helicobacter pylori infection, use of nonsteroidal anti-inflammatory drugs (NSAIDs), infectious disease, IBD, tropical sprue, collagen vascular and connective tissue disorders, other food hypersensitivities, drugs, and even morbid obesity. ${ }^{40-42,51}$ Therefore, the diagnosis of GSE is clinicopathological and must not be made on histological grounds alone. At our institutions, we make the diagnosis of fully developed or partially developed 'sprue-like changes' depending on the degree of alteration. These findings are then correlated with clinical findings, including serology, in order to make the diagnosis.

The serum of patients with GSE contains several antibodies indicative of the immunological nature of the disorder. ${ }^{28,29,37,52,53}$ These include antibodies to gliadin, an alcohol-soluble peptide fraction of gluten, and to tissue transglutaminase (TTG), an enzyme which modifies gliadin enhancing the cell-mediated immune response to the substance. One TTG-modified gliadin peptide has been found to be the dominant epitope in the response. ${ }^{52}$ Anti-TTG antibodies are closely related to antiendomysial antibodies, previously seen as the most sensitive and specific serological test for GSE. The use of enzyme-linked immunosorbent assay (ELISA) for anti-TTG antibodies has significantly increased the ease and sensitivity of serological testing for GSE and is now seen as the most sensitive assay for the disorder; antiendomysial antibodies remain more specific, however. ${ }^{28,54,55}$ The immune nature of GSE is reinforced by the finding that patients suffering with this disease have a highly significant excess of other autoimmune diseases, such as Type 1 diabetes mellitus and autoimmune thyroiditis. ${ }^{28,56}$ Furthermore, studies have shown that gluten/gliadin do not directly cause injury to mucosal cells in tissue culture from patients with GSE, but instead rely on an 'endogenous mediator' to create the mucosal damage. Activated immune cells and their products such as cytokines are thought to be this tissue-borne factor. ${ }^{57,58}$

The final component in the clinicopathological diagnosis of GSE is the institution of a gluten-free diet (GFD). The hallmark of GSE is the abatement of symptoms and the return of mucosal biopsies to nearnormal when gluten-containing foods are removed from the patient's intake. ${ }^{59-61}$ Within the first 3 months, even as soon as 1 week, symptoms should markedly improve. On biopsy, the surface epithelial injury decreases, as does the number of IELs. Villi begin to reconstitute. On a long-term GFD, the mucosal architecture may return completely to normal. If gluten is restored to the diet, symptoms and histological abnormalities quickly return, led by the return of IELs at the tips of the villi. ${ }^{61}$

In addition to the immunological issues already discussed, genetic and environmental factors are also thought to contribute to the pathogenesis of GSE. The disease is known to run in families, with 10$22 \%$ prevalence in first-degree relatives of GSE patients. $^{28,62-65}$ There is also a high, but less than $100 \%$, concordance of disease in identical twin pairs. ${ }^{28,29}$ The major histocompatibility complex heterodimer HLA-DQ $(\alpha 1 * 501, \beta 1 * 0201)$, also known as HLA-DQ2, is found in $>95 \%$ of patients, as opposed to $20-30 \%$ prevalence in the general population. ${ }^{31}$ This HLA antigen is involved in the presentation of gliadinderived peptides to host $\mathrm{T}$ cells. ${ }^{5,66}$ Those patients that are negative for HLA-DQ2 are usually positive for HLA-DQ8. ${ }^{29,52}$

Evidence of an environmental factor in the pathogenesis of GSE comes from the lack of full concordance in identical twins. Also, one study has shown serological evidence of exposure to adenovirus type 12 in a disproportionately high number of GSE patients. ${ }^{67}$ Although this study has not been replicated, this type of adenovirus is known to share an amino acid sequence with gliadin, making the hypothesis an attractive one.

Several variants of GSE exist, as well as a related autoimmune disease. So-called 'latent coeliac disease' is used to describe patients with evidence of gluten sensitivity, but without full-blown symptoms of sprue. Alluded to above, this condition requires vigilance on histopathological examination, as the findings may occur along a spectrum from increased IELs to nearly full-blown sprue-like changes. Such patients all have antigliadin antibodies, including IgA and IgM antibodies, in their intestinal secretions. 'Collagenous sprue' 
refers to a variant entity having a thick collagen table beneath the mucosa, which also has the more typical changes of GSE. ${ }^{68}$

Refractory coeliac disease refers to the situation in which the patient's symptoms and biopsy changes fail to respond to a gluten-free diet. ${ }^{28,69,70}$ Such patients generally have a poor prognosis, and are at higher risk for development of enteropathy-associated T-cell lymphoma (EATCL), an aggressive form of non-Hodgkin's lymphoma originating in the intestine. Approximately $80 \%$ of refractory coeliac disease patients have clonal lymphocyte populations in the intestine, which can be proven using T-cell receptor $\gamma$ gene rearrangement studies. ${ }^{49,71}$ EATCL is composed of cytotoxic T lymphocytes with an aberrant CD4-/CD8-immunophenotype and probably accounts for the majority of cases of what has been termed 'ulcerating sprue'. In addition to EATCL, GSE patients are at increased risk of the development of other non-Hodgkin's lymphomas, intestinal adenocarcinoma and squamous cell carcinoma of the oesophagus. ${ }^{29,56,72-75}$

Finally, GSE is associated with the blistering skin disorder dermatitis herpetiformis (DH) ${ }^{28,76}$ Approximately $60-80 \%$ of patients with $\mathrm{DH}$ are found to have classic GSE, with response to a gluten-free diet. ${ }^{27,77}$ Furthermore, GSE is more common in relatives of patients with $\mathrm{DH}$ and there is overlap in HLA phenotypes between patients with GSE and DH. ${ }^{76,78}$ The diseases appear to be different points along a spectrum that includes both skin and intestinal mucosal abnormalities, as both conditions have similar genetic characteristics. $^{27,56,79-81}$

\section{Tropical sprue}

Tropical sprue (TS) is an intestinal malabsorption syndrome with a well-known and specific geographical distribution, affecting residents of (or visitors to) the tropics, including Puerto Rico, the Caribbean, northern South America, West Africa, India and south-east Asia. ${ }^{27,82}$ The histological findings, while similar to those of GSE, are not identical, and a totally flat intestinal mucosa is rare in $\mathrm{TS}^{83-85}$ However, villous blunting with concomitant crypt hyperplasia is common, and the epithelial dysfunction characteristic of GSE is central to the pathogenesis of TS (Figure 3).

Whereas GSE shows mucosal changes most significantly in the proximal small intestine, the changes of TS are equally prominent in the ileum and in the proximal jejunum, at least in well-established disease. ${ }^{85}$ This distribution explains the more common association of TS with megaloblastic anaemia caused by vitamin B12 and folate deficiency, which is much less common in

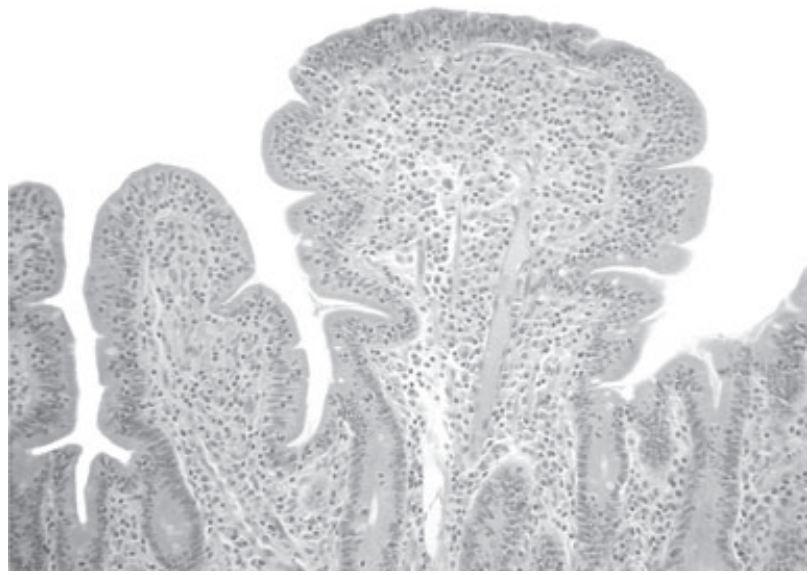

Figure 3. Medium-power view of tropical sprue showing villous blunting and distortion with increased intraepithelial lymphocytes resembling a Marsh 2 lesion of gluten-sensitive enteropathy.

GSE. Similar nuclear-cytoplasmic maturational dissociation (nuclear enlargement, decreased mitotic figures) may be observed in the enterocytes as well. ${ }^{27,86}$

Much evidence points to an infectious aetiology for TS. Indeed, the disease has also been dubbed 'postinfective tropical malabsorption' ${ }^{87,88}$ The geographical distribution certainly supports this conclusion. While no definite causal organism has been elucidated, broadspectrum antibiotic therapy usually results in rapid recovery. ${ }^{27,86,89}$ Furthermore, it is known that overgrowth of aerobic enteric bacteria is found in TS patients and that such bacteria may be toxin-producing. ${ }^{89,90}$ This differs from overgrowth of anaerobic bacteria such as occurs in the blind loop or stasis syndrome, which is discussed below. Finally, some have postulated that protozoan infection, such as cyclospora, may also play a role in the aetiologyof TS. ${ }^{91}$

\section{Autoimmune enteropathy}

Autoimmune enteropathy (AE) is probably a family of diseases and, while it occurs primarily in young children, can also be found in adults. ${ }^{92-94}$ The histological findings of villous blunting and crypt hyperplasia are similar to those seen in GSE, but the resultant intractable secretory diarrhoea is unresponsive to a gluten-free diet, as well as to total parenteral nutrition (TPN). ${ }^{94}$ In young males, the Endocrinopathy is associated with Immune dysregulation, Polyendocrinopathy and X-linkage (IPEX) and has been shown to be the result of a germ-line mutation in the FOXP 3 gene on the X chromosome. ${ }^{95-97}$

The hallmark of $\mathrm{AE}$ is its association with antienterocyte antibodies. ${ }^{94}$ Some patients may also have 
antigoblet cell, antiparietal cell and/or anti-islet cell antibodies. ${ }^{98,99}$ The mucosae of the stomach and colon may also be affected. While IELs may be increased in the intestinal epithelium, the intense surface lymphocytosis characteristic of GSE is not present and neutrophils are more commonly seen. Lymphocytic infiltrates may be found in the deeper mucosa along with apoptotic debris. ${ }^{94}$ Patients with antigoblet cell antibodies have a lack of goblet cells, enteroendocrine cells and Paneth cells on biopsy. The autoimmune nature of the condition is supported by its response to steroids and immunosuppressive medications such as tacrolimus, cyclosporin and methotrexate. ${ }^{92}$

\section{Intestinal lymphangiectasia}

Abnormal dilation of the intestinal lymphatics/lacteals is associated with malabsorption, resulting in proteinlosing enteropathy, steatorrhoea, peripheral oedema and lymphyocytopenia. ${ }^{86,100-102}$ The condition is commonly seen secondarily in a variety of disorders, including carcinoma, lymphoma, IBD and others. ${ }^{103,104}$ However, a rare primary form of the disorder occurs also, known as primary intestinal lymphangiectasia (PIL). This is usually found in young children and is apparently a congenital defect, characterized by marked structural abnormalities of lymphatic channels, which result in lymph stasis and which may also be seen in the extremities. ${ }^{86}$ The resultant lymph leakage results in loss of proteins, as well as of numerous fat-soluble vitamins and nutrients. The striking loss of protein results not only in hypoalbuminaemia and oedema, but also in a decrease in immunoglobulins. Along with abnormalities in T-cell populations seen in the disorder, this can lead to an immunodeficient state. ${ }^{105,106}$

Grossly, the intestinal mucosa can have a 'spotted' appearance, with many white dots (the dilated lacteals), especially at the villous tips. ${ }^{107,108}$ Histologically, the villi are blunted and there is oedema of the lamina propria. Lymphatic channels are dilated throughout the bowel wall and are lined by endothelial cells. This appearance may extend into mesenteric lymph nodes as well. ${ }^{109}$ The channels may contain foamy macrophages and proteinaceous debris. The differential diagnosis includes Whipple's disease, an isolated lymphangioma as well as pneumatosis intestinalis. The changes of PIL can be patchy, with numerous lymphangioma-like collections of abnormal lymphatics. ${ }^{86}$ Therefore, multiple biopsies may be needed in order to make the diagnosis. Secondary lymphangiectasia usually shows diffuse dilation of lymphatics, a difference that may aid in diagnosis.

\section{Inflammatory bowel disease}

A comprehensive discussion of IBD is beyond the scope of this review. However, there are many ways in which IBD may lead to intestinal malabsorption. In particular, Crohn's disease (CD) may affect the GI tract from the mouth to the anus, and may have extensive small intestinal involvement. While ulcerative colitis (UC) has traditionally been viewed as affecting only the colon and rectum with occasional terminal ileal inflammation ('backwash ileitis'), more recent studies have noted diffuse duodenitis in patients with otherwise classic UC. ${ }^{110-112}$

Regardless of the type of IBD, significant mucosal involvement in the small bowel may lead to a physical diminution of mucosal area, leading to malabsorption. In addition, dense mural scarring as occurs in CD may result in obstruction of lymphatic outflow, causing secondary lymphangiectasia. Perhaps most common is the creation of fistulous tracts in $\mathrm{CD}$, leading to a bypass of the digestive stream. Entero-enteric or enterocolic fistulae may result in a functional loss of a variable amount of mucosal area as described in the first part of this review, as well as to stasis and bacterial overgrowth, discussed below. ${ }^{27}$

\section{Acrodermatitis enteropathica}

This autosomal recessive condition leads to the malabsorption of zinc. It is associated with a variety of skin and mucosal abnormalities, the latter including villous blunting, crypt hyperplasia, increased lamina propria inflammatory cells and a loss of brush border enzymes. ${ }^{86}$ These changes may lead to further malabsorption by mechanisms already described.

\section{MURAL DISEASE}

Conditions specific to the small intestinal wall may cause malabsorption by a variety of mechanisms. The classic example of a mural disease leading to malabsorption is that of systemic sclerosis (so-called 'scleroderma of the small bowel'). The primary lesion in this condition is not of the mucosa, but of the muscularis propria, where the smooth muscle fibres are replaced by collagen/fibrosis. These changes, visible on a trichrome stain, are most prominent in the inner (circular) muscularis layer and result in upstream dilation and diverticulum formation (Figure 4). ${ }^{113-115}$

The resultant loss of peristaltic activity leads to stasis, bacterial overgrowth and blind loop formation, which may lead to malabsorption by mechanisms discussed below. ${ }^{116-119}$ While systemic sclerosis is the classic mural disease leading to malabsorption, identical 

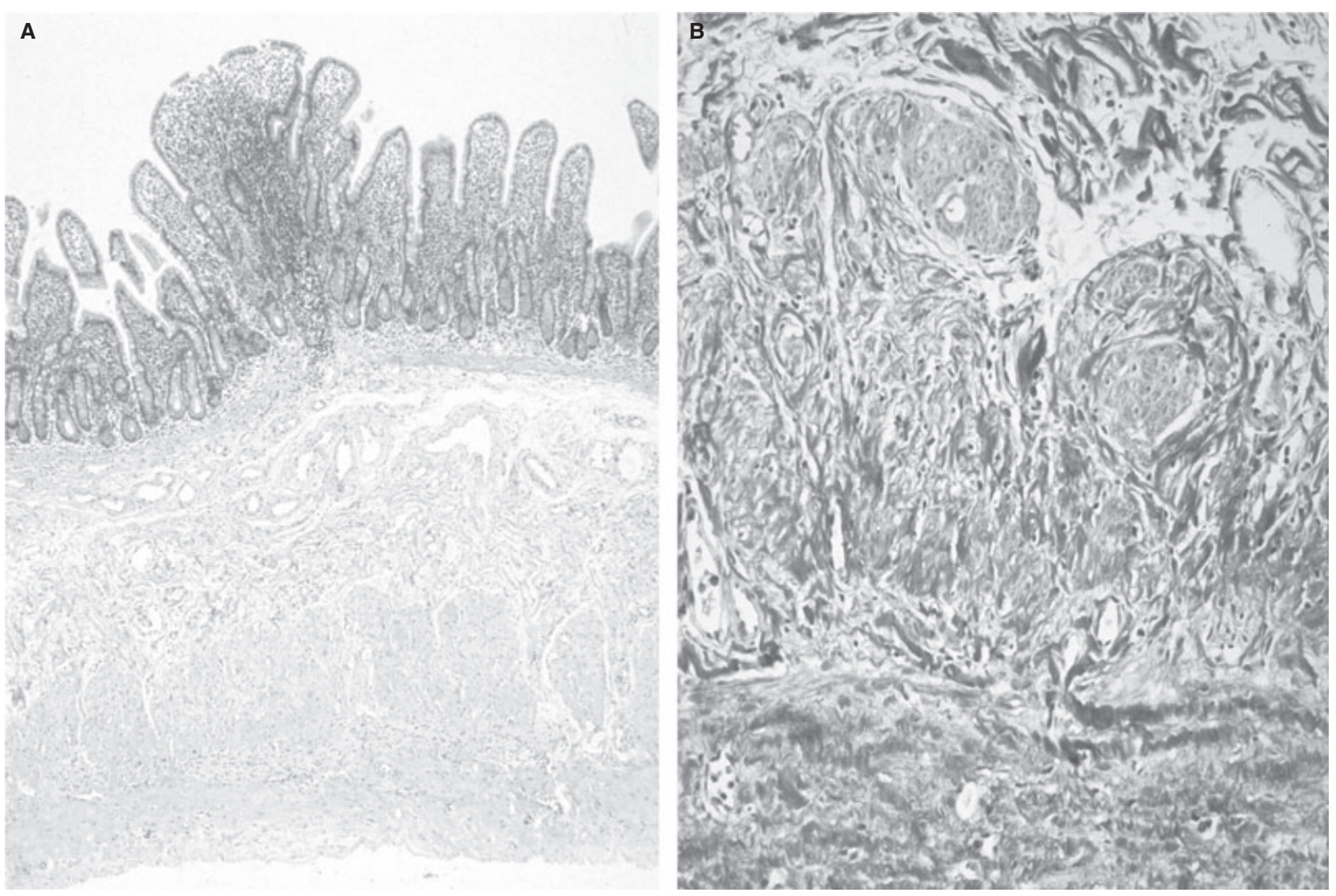

Figure 4. Scleroderma affecting the small intestine. A, Low-power H\&E-stained section shows mild to moderate villous blunting with increased lamina propria inflammation. These mildly abnormal non-specific mucosal changes are typical of bacterial overgrowth. The muscularis propria looks nondescript. B, Trichrome-stained section of the muscularis propria showing that nearly all of the smooth muscle has been replaced with collagen, indicative of the patient's underlying motility disorder.

problems may be the result of a variety of neuromuscular disorders, including diabetic neuropathy, amyloidosis, disturbances of the intestinal neuronal plexi, small intestinal diverticula of other aetiology, CD (see above), surgical intervention, familial neuropathies and myopathies, and many others. ${ }^{27,120,121}$

\section{IMMUNODEFICIENCY AND HIV/AIDS-RELATED ENTEROPATHY}

Immunodeficiency states are commonly associated with malabsorption and diarrhoea, often resulting from secondary or opportunistic infections. Small bowel biopsies may show inflammatory changes in the mucosa, decreased lymphoid tissue and/or alteration of lymphocyte populations, and the presence of infectious organisms or their sequelae, including viruses (viral inclusions), bacteria, fungi and/or parasites. ${ }^{122-129}$ The immunodeficiency states may be divided into primary, including selective IgA deficiency and common variable immunodeficiency, and secondary, including iatrogenic, immunoglobulin loss from severe proteinlosing enteropathy, and HIV / AIDS.

The association of AIDS with diarrhoea, malabsorption and weight loss has been well described. ${ }^{130-132}$ Often, there is a secondary cause of diarrhoea in the form of an opportunistic infection, such as with Giardia or Cryptosporidium (see below). ${ }^{133-139}$ However, a proportion of HIV/AIDS patients have such symptoms in the absence of an identifiable infection. This has been termed 'idiopathic AIDS enteropathy' and these patients have a set of mucosal abnormalities on biopsy, including shortened villi (usually with normal crypt depth), a general increase in chronic inflammatory cells and alterations in the mucosal lymphocyte population. ${ }^{140-145}$ Immunohistochemical studies show a decrease in the number of CD4+ helper $\mathrm{T}$ cells, increased CD8+ suppressor $\mathrm{T}$ cells, depletion of IgA+ plasma cells and an increase in IgM+ plasma cells. ${ }^{146-152}$ HIV patients may also manifest malabsorp- 
tion of fats and vitamin B12, as well as secondary lactase deficiency. ${ }^{153-157}$ Although the exact pathogenesis of these changes is not known, they may be related to undetected secondary infection(s), immune dysregulation, an epithelial maturation problem, or the direct effect of the HIV agent or one of its products. ${ }^{133,158-162}$ Fortunately, the advent of better antiviral therapy for HIV has markedly decreased the number of patients with GI symptoms in developed countries. $^{163}$

\section{Microbial causes of malabsorption}

\section{BACTERIAL OVERGROWTH}

The normal small intestine contains a cadre of flora crucial to proper bowel function. Different microenvironments, or 'niches', are created by mucosal folds and crypt structures, and are normally colonized by obligate or facultative anaerobic bacteria, most significantly Bacteroides species. These organisms are most abundant in the distal ileum, while different bacteria, including species ingested with food-largely aerobes and facultative anaerobes-dominate in the more proximal small bowel. ${ }^{27,164}$

Any disruption in the normal 'ecology' of the small bowel, as by conditions leading to stasis, blind loops or altered (decreased or increased) transit time, may result in diarrhoea and malabsorption. ${ }^{165-167}$ Fistulae and other non-native connections may be created by disease or iatrogenically (e.g. in Billroth procedures). Motility disorders like systemic sclerosis or neuromuscular diseases may create stasis and blind intestinal loops. Conditions leading to structural or functional loss of the gastric reservoir or of gastric acid production (gastrectomy, diabetes, autoimmune atrophic gastritis) may lead to the rapid 'dumping' of large quantities of poorly acidified food into the small intestine. All of these scenarios can lead to alterations in intestinal flora and resultant malabsorption. Furthermore, the introduction of non-indigenous species may lead to deconjugation of bile acids by the bacteria, creating steatorrhoea and potentially altering vitamin B12 absorption. ${ }^{164}$

Typically, patients with bacterial overgrowth are elderly and exhibit diarrhoea and weight loss. ${ }^{168,169}$ The mucosal histology may be normal, but often shows villous blunting of variable degree and/or an increase in chronic inflammatory cells (Figure 4A). ${ }^{27,116,170,171}$ Intraepithelial neutrophils and/or lymphocytes are often present. These findings are most often patchy and this feature can be helpful in distinguishing bacterial overgrowth from GSE, which is typically diffuse. ${ }^{116}$ With continued perturbation of the bacterial ecology, brush border damage may ensue, further compromising sugar, fat and amino acid uptake. ${ }^{117,172-174}$ Because of the change in luminal contents, there may be an increase in luminal antigliadin antibodies, which could lead to a mistaken diagnosis of GSE. ${ }^{175}$ Antibiotic therapy is helpful in eradicating abnormal bacteria and restoring the native ecology.

\section{WHIPPLE'S DISEASE}

Described in 1907 by George Whipple, then a faculty member at the Johns Hopkins Medical School, this disorder was originally termed 'intestinal lipodystrophy', as it was thought to be a disorder of lipid metabolism. ${ }^{176} \mathrm{~A}$ relatively rare entity, about which much has been written, Whipple's disease (WD) disproportionately affects middle-aged white males (male:female ratio $8: 1$ ), causing diarrhoea and weight loss along with fever, arthralgias and abdominal pain. It is a systemic disorder, also causing systemic lymphadenopathy, endocarditis, pulmonary and central nervous system (CNS) disease. Some patients present primarily with neurological symptoms and/or with fever of unknown origin and have minor or absent GI findings. ${ }^{177-181}$

Susceptibility to WD, now known to be an infectious disease caused by Tropheryma whipplei, a Gram-positive bacillus, may be related to an underlying defect in the host immune system. ${ }^{182}$ Studies have shown a decreased CD4:CD8 ratio in $\mathrm{T}$ cells, as well as a decrease in immunocompetent $\mathrm{B}$ cells. There is an association with the HLA-B27 and some patients are also infected with other GI pathogens, such as Giardia. Abnormal histiocyte function may underlie the accumulation of organisms, possibly related to abnormal phagocytosis and/or decreased interleukin-12 production. ${ }^{177,183-187}$ However, whether these immune defects predispose to or merely result from infection has not been conclusively proven.

Grossly (or endoscopically), the intestinal folds in a case of WD may be thickened, sometimes with yellow or white deposits visible. Histologically, the villi are rounded and blunted, with dilated lacteals (Figure 5). The lymphatic channels are dilated throughout the intestinal wall as well. Closer examination reveals that they are distended with lipid- and organism-laden macrophages. These stain positively with periodic acid-Schiff (PAS) stain and are diastase resistant (Figure 6). This stain highlights the partially digested organisms within the macrophage phagolysosomes, which appear as granular inclusions. Intact, rod-shaped organisms are present free 


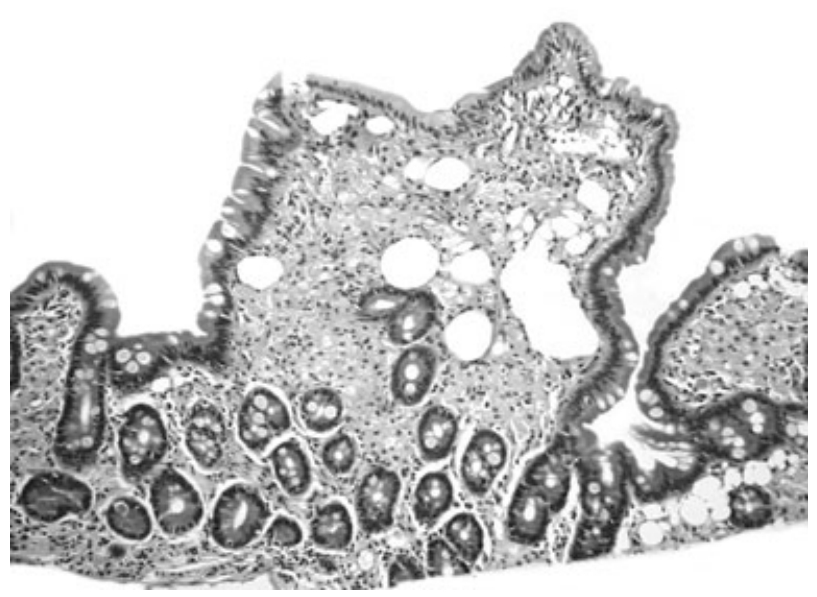

Figure 5. Low-power view of Whipple's disease showing distorted/ blunted villi containing foamy histiocytes and dilated lacteals.

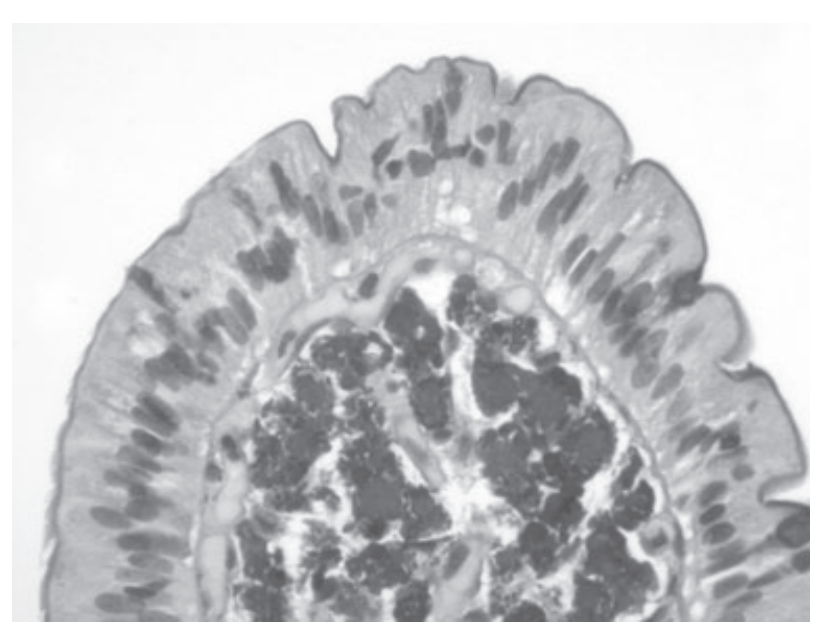

Figure 6. High-power periodic acid-Schiff (PAS) diastase-stained section of Whipple's disease showing characteristic macrophages containing granular PAS+ deposits.

in the tissue as well, and may also be seen within other cell types, including fibroblasts, plasma cells, lymphocytes, mast cells and epithelial cells. ${ }^{177,178,180}$

The pathological diagnosis of WD depends on adequate biopsy sampling, because the distribution of the classic findings may be patchy. A submucosal variant of the condition exists and can be very difficult to diagnose without adequate clinical suspicion, because the classic mucosal changes are not present. ${ }^{188}$ It is possible that this variant is simply a partially treated form of the disease, perhaps resulting from antibiotic treatment for some other infection that eradicates the mucosal disease but not CNS infection. After adequate antibiotic treatment, the PAS+ granular inclusions may persist within macrophages for years and do not indicate relapse or persistent disease. Only the identification of intact bacteria, which may be more easily visible on silver-based stains or electron microscopy, indicates inadequate treatment. Response to therapy can also be followed with polymerase chain reaction assays, which are now available. ${ }^{178,183,184}$

The differential diagnosis includes other causes of secondary intestinal lymphangiectasia and lymphadenopathy. ${ }^{189,190}$ Perhaps the most important differential diagnosis is of Mycobacterium avium complex, a disease largely affecting immunocompromised hosts. This entity may look nearly identical to WD on biopsy, and may also be seen in numerous extraintestinal sites (Figures 7 and 8). Acid-fast stains are necessary to differentiate these two conditions.

\section{GIARDIASIS}

Giardia lamblia is the most prevalent parasite worldwide and has received increased attention with the advent of immunosuppressive diseases such as HIV/AIDS, as well as with increased use of immunosuppressive therapy. ${ }^{27}$ Patients with giardiasis may be entirely asymptomatic, or may have severe diarrhoea and steatorrhoea with copious, foul-smelling stools. When present, this is accompanied by bloating, abdominal distension and flatus, which may result in significant malabsorption and weight loss. The latter outcome is significantly more likely in immunocompromised patients. ${ }^{27,124}$ Transmission is faecal-oral and usually involves the ingestion of contaminated water, but may also come from intimate sexual contact. ${ }^{192}$ The cyst form is ingested, and the trophozoite form emerges in the upper GI tract, where it may be seen on biopsy. In the distal small bowel, the organism encysts again and is passed in the faeces.

Faecal ova and parasite examination and duodenal aspirates show the organism best, but it can be seen on routine haematoxylin and eosin (H\&E) preparations of duodenal biopsies. ${ }^{193}$ The trophozoite form is pearshaped and binucleate, giving the appearance of a face with two 'eyes' staring back at the observer when viewed ventrally; a more sickle-like shape is evident on lateral view (Figure 9A). However, they may be quite difficult to see, and their appearance depends on their orientation on the biopsy. As such, they may disappear in or masquerade as the clumps of mucus often seen in partially crushed duodenal biopsies and a high index of suspicion is necessary for diagnosis. Conversely, the diagnosis probably should not be made unless one can see the organisms' nuclei. ${ }^{194}$ Trichrome and/or Giemsa stains may be helpful in highlighting the trophozoites. The accompanying mucosal histology is variable, and 

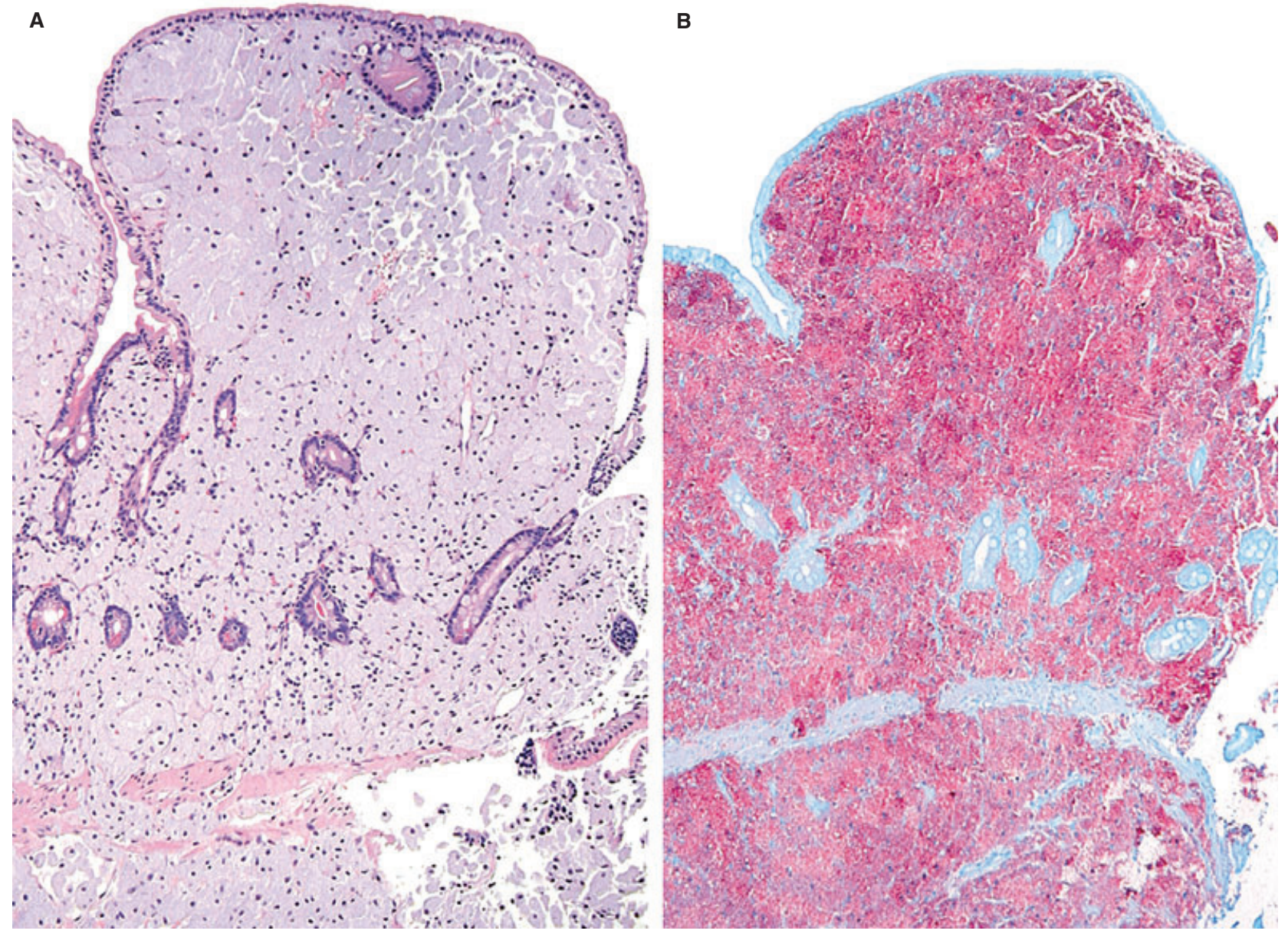

Figure 7. Low-power composite of Mycobacterium Avium complex in an AIDS patient. A, H\&E-stained section mimicking the changes of Whipple's disease seen in Figure 5. B, AFB stain showing diffuse positivity.

often normal. ${ }^{27,195}$ If abnormal, it may consist of mild villous blunting, or may strongly resemble the changes in GSE. ${ }^{196}$ The more striking changes are especially common in patients predisposed to infection by hypogammaglobulinaemia. ${ }^{124}$ The differential diagnosis must include other causes of malabsorption, as well as other infectious causes of diarrhoea, such as amoeba, Cryptosporidia and helminths. ${ }^{191}$

\section{CRYPTOSPORIDIOSIS}

Cryptosporidium parvum is a coccidial parasite found commonly in water. It more commonly affects animals than humans, but can be passed to humans as a zoonosis, usually causing only a short, self-limited bout of diarrhoea in immunocompetent hosts. However, it can cause chronic, possibly lethal, intestinal disease in immunocompromised patients. ${ }^{27,197-201}$ The organisms are small $(2-4 \mu \mathrm{m})$ and round, appearing as basophilic bodies within the brush border on intestinal biopsies, especially near the villous tips (Figure 9B). On electron microscopy, they are seen to be intracytoplasmic. In addition to the small bowel, cryptosporidia may be found in the stomach and colon and have been reported in the bronchi, the pancreaticobilliary system and the gallbladder. ${ }^{27,202}$

\section{MICROSPORIDIOSIS}

Phylum Microspora consists of a large number $(>100$ genera and around 1000 species) of primitive protozoa whose primary hosts are fish and arthropods. ${ }^{27,203}$ These organisms are characterized by the production of unique spores that contain a hollow, coiled tube called a 'polar tubule', through which infective material known as 'sporoplasm' may be injected into a host cell. While immunocompetent hosts have little risk of a serious infection, the increase in immunosuppressive diseases and therapies has brought more attention to these organisms. ${ }^{133,204-210}$ 

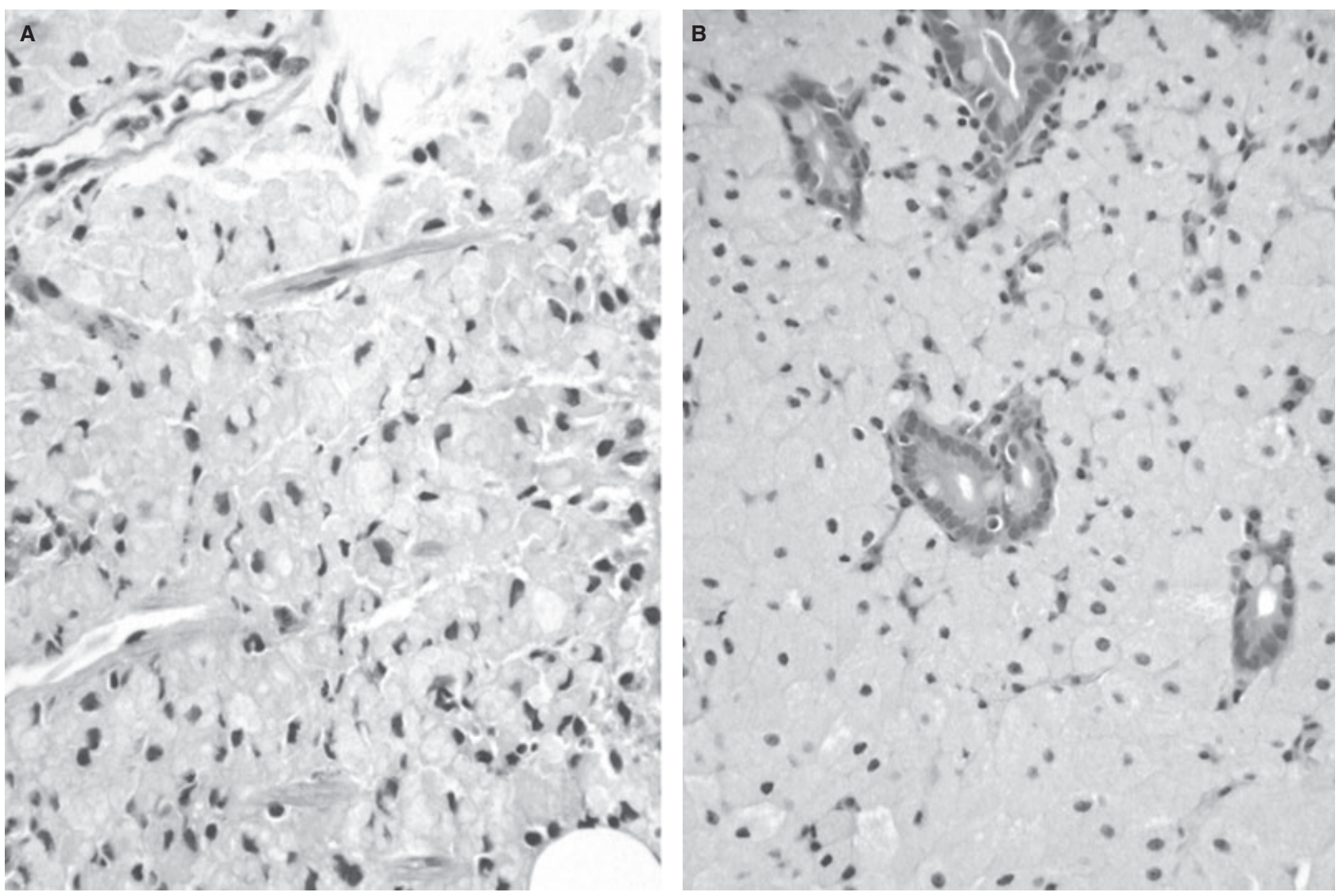

Figure 8. A, High-power view of macrophages in Whipple's disease. B, High-power view of macrophages in Mycobacterium Avium complex (MAC). Note the Whipple's macrophages have lipid vacuoles while the MAC macrophages do not.

Despite the large number of organisms in this phylum, most human microsporidial disease is caused by two species. Other species cause a variety of diseases including myositis, keratoconjunctivitis, sinusitis and many others. ${ }^{210}$ Their minute size (as small as $1 \mu \mathrm{m}$ ) and poor staining quality makes them very difficult to detect on conventional H\&E preparations. Formerly, electron microscopic (EM) diagnosis was necessary, but the use of special stains has made light microscopic diagnosis more frequent. ${ }^{211,212}$

\section{Enterocytozoon bieneusi}

Of the two microsporidia most frequently found in humans Enterocytozoon bieneusi is the most common, with a prevalence of $9-16 \%$ in HIV patients with chronic diarrhoea by stool studies. ${ }^{204,206-208,210,213}$ Like other organisms discussed in this section, it may cause a self-limited, probably underdiagnosed, diarrhoeal illness in immunocompetent hosts. Immunosuppressed patients often develop much more serious, possibly chronic, disease, especially those AIDS patients with very low CD4 lymphocyte counts. ${ }^{214}$ Infected patients most commonly report chronic diarrhoea, anorexia and weight loss, with less frequent reports of abdominal pain, nausea, vomiting and fever. While previously thought to be restricted to the small intestine, it is now known that the organism may be found in the biliary tract. ${ }^{210,214}$ The latter symptoms are more frequent in patients with biliary involvement and may progress to a full-blown clinical picture of cholangitis or cholecystitis. Treatment is supportive.

The diagnosis formerly relied on EM, which revealed two phases of the life cycle. A proliferative phase, known as merogony, and a sporulating phase, known as sporogony. ${ }^{203,214}$ The proliferative phase consists of small, rounded organisms with one to six nuclei found within cells, where they are more electron-lucent than the surrounding cytoplasm and contain so-called electron-lucent inclusions, or empty clefts. In contrast, the sporulating phase is characterized by the presence of electron-dense stacks of discs, which later aggregate to form the polar tubule. Nuclear division results in up to 12 nuclei, each surrounded by coiled polar tubules. These forms later 

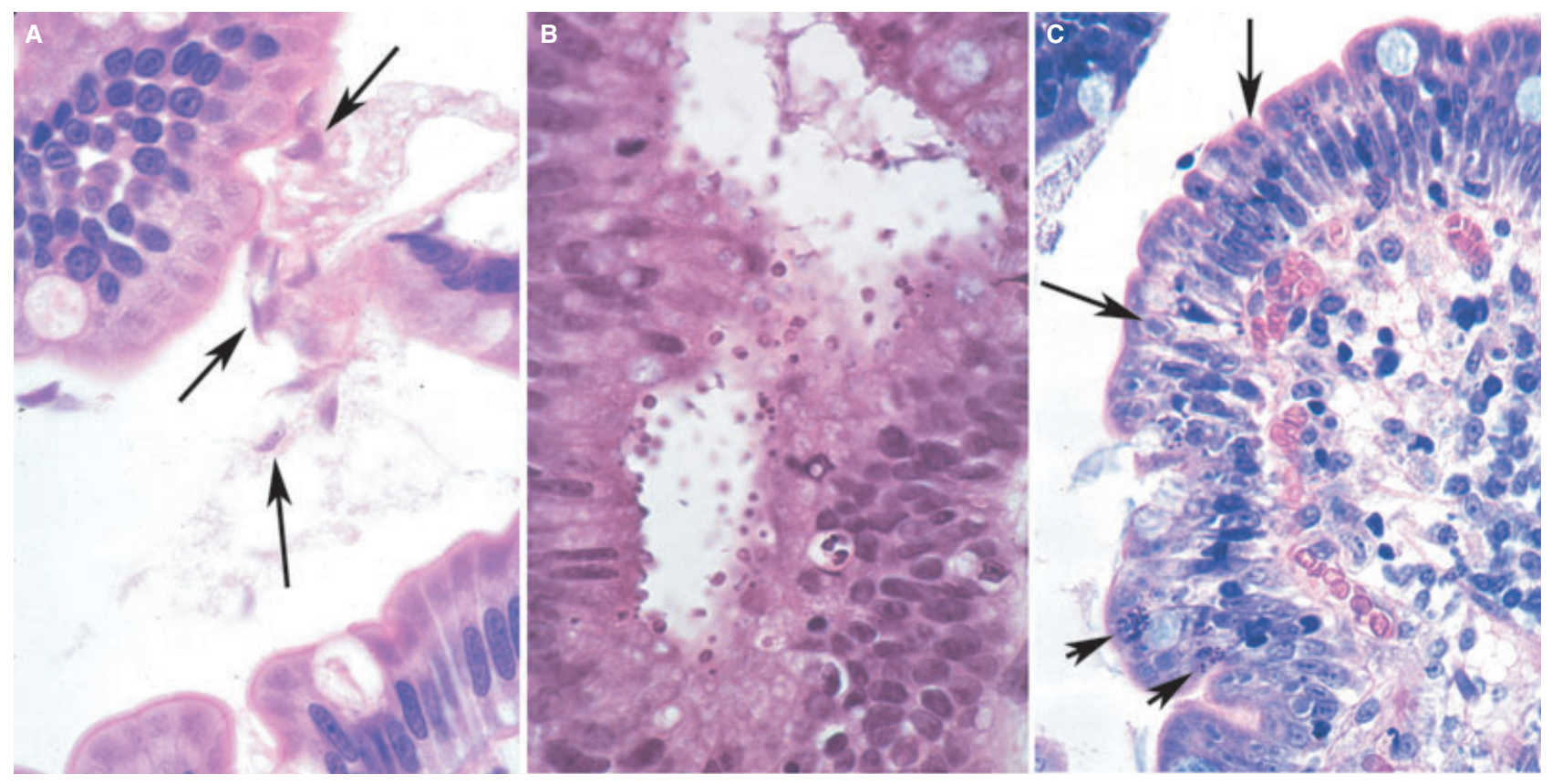

Figure 9. Composite of infectious lesions of the small bowel. A, High-power view of Giardia lamblia. Arrows show several binucleate trophozoites. Numerous less well-preserved organisms are also present resembling amorphous clumps of mucin. B, High-power view of Cryptosporidium parvum. Numerous round basophilic organisms appear to be budding off of the luminal surface. Note the variability in size and the presence of internal structures; these features help distinguish true organisms from mucin droplets. C, High-power view of Enterocytozoon bieneusi (microsporidia). This Giemsa-stained section highlights the spores (short arrows), whereas the organisms themselves are harder to see (long arrows).

disaggregate into spores, which are very electrondense and contain one nucleus. Both phases can be found in the apical (supranuclear) portion of enterocytes, free within the cytoplasm.

By light microscopy, affected mucosa shows villous blunting, with organisms concentrated at the villous tips. ${ }^{210}$ IELs are increased and infected enterocytes may shed into the lumen. On H\&E preparations, proliferating organisms may be seen in the supranuclear cytoplasm and may indent the enterocyte nucleus and/or be surrounded by a clear halo. Special stains, including Gram stain (positive), trichrome, WarthinStarry and Giemsa, help in visualizing the spores (Figure 9C) and the diagnosis is tenuous without the aid of such stains. Jejunal biopsies have the highest diagnostic yield, although duodenal and ileal biopsies may still be diagnostic. Stool examination may reveal spores using calcofluor white or trichrome stain, but care should be taken to distinguish them from yeasts such as Candida. The latter are more homogeneous and more round, without internal spore structure.

\section{Encephalitizoon intestinalis}

Formerly called Septata intestinalis, Encephalitizoon intestinalis is the less common of the two Microsporidia most commonly infecting humans. However, it is important to recognize, because effective treatment is available, in contrast to E. bieneusi. ${ }^{214,215}$ While it also involves the intestine and the biliary system, it may become more systemic as well, affecting the respiratory and urinary tracts, and the conjunctiva. ${ }^{210}$ The primary clinical symptoms are again severe diarrhoea and weight loss, with the possibility of a sclerosing cholangitis-like clinical picture in patients with biliary involvement. Unlike E. bieneusi, there may more frequently be sinusitis, bronchitis and conjunctivitis as well. Treatment with albendazole results in rapid resolution of symptoms, but relapses may occur when therapy is discontinued.

The diagnosis is very similar to that of E. bieneusi, with similar phases seen on EM. ${ }^{214}$ However, maturation occurs within a cluster in the host cytoplasm, with more mature phases occurring more peripherally in the cluster. In addition, E. intestinalis develops a fine fibrillar network within the host cell, and the spores may appear to be embedded within a honeycomb-like structure. By light microscopy, the organisms look very similar to E. bieneusi, but may be more refractile. Furthermore, Gram stain will also reveal spores within macrophages, fibroblasts and endothelial cells in addition to enterocytes. ${ }^{214}$ Cytological examination may also reveal the organisms in 
urine, nasal smears and sputum, and spores can be found in the stool, being somewhat larger than those of E. bieneusi.

\section{Conclusion}

The causes of small intestinal malabsorption are protean, but can most easily be organized into three basic types. Maldigestive causes arise from problems with mixing or with digestive mediators, such as occur after gastrectomy and in deficiencies of pancreatic or intestinal enzymes, or of bile salts. Mucosal and mural problems include a very broad group of diseases, and comprise perhaps the most commonly thought of causes of malabsorption. These include gluten-sensitive enteropathy, tropical sprue and autoimmune enteropathy, mural diseases such as systemic sclerosis, and HIV/AIDS-related enteropathy. Finally, microbial causes of malabsorption include bacterial overgrowth, the much-studied Whipple's disease, and infections/infestations most commonly seen in immunocompromised hosts, such as giardiasis, cryptosporidiosis and microsporidiosis. Although neither exhaustive nor comprehensive, this review has attempted a discussion of the most common and the most interesting entities within each of these categories.

\section{References}

1. Johnson LR. Gastrointestinal physiology. Philadelphia: Mosby 2001.

2. Brasitus TA, Sitrin MD. Intestinal malabsorption syndromes. Annu. Rev. Med. 1990; 41; 339-347.

3. Griffiths A, Taylor RH. Postgastrectomy pancreatic malabsorption: is there a case for intervention? Eur. J. Gastroenterol. Hepatol. 1999; 11; 231-237.

4. Maes BD, Hiele MI, Geypens BJ, Ghoos YF, Rutgeerts PJ. Gastric emptying of the liquid, solid and oil phase of a meal in normal volunteers and patients with Billroth II gastrojejunostomy. Eur. J. Clin. Invest. 1998; 28; 197-204.

5. Bae JM, Park JW, Yang HK, Kim JP. Nutritional status of gastric cancer patients after total gastrectomy. World J. Surg. 1999; 23; 983-984.

6. Friess H, Bohm J, Muller MW et al. Maldigestion after total gastrectomy is associated with pancreatic insufficiency. Am. J. Gastroenterol. 1996; 91; 341-347.

7. Meyer JH. Nutritional outcomes of gastric operations. Gastroenterol. Clin. North Am. 1994; 23; 227-260.

8. Kreckler S, Dowson H, Willson P. Dumping syndrome as a complication of laparoscopic Nissen fundoplication in an adult. JSLS 2006; 10; 94-96.

9. Abell TL, Minocha A. Gastrointestinal complications of bariatric surgery: diagnosis and therapy. Am. J. Med. Sci. 2006; 331; 214-218.

10. Connor F. Gastrointestinal complications of fundoplication. Curr. Gastroenterol. Report 2005; 7; 219-226.
11. Gilger MA, Yeh C, Chiang J, Dietrich C, Brandt ML, El-Seraq HB. Outcomes of surgical fundoplication in children. Clin. Gastroenterol. Hepatol. 2004; 2; 978-984.

12. Ukleja A. Dumping syndrome: pathophysiology and treatment. Nutr. Clin. Pract. 2005; 20; 517-525.

13. Bouras EP, Scolapio JS. Gastric motility disorders: management that optimizes nutritional status. J. Clin. Gastroenterol. 2004; 38; 549-557.

14. Saito A, Noguchi Y, Yoshikawa T et al. Gastrectomized patients are in a state of chronic protein malnutrition: analyses of 23 amino acids. Hepatogastroenterology 2001; 48; 585-589.

15. Wenig BM, Heffess CS. Inflammatory, infectious, and other nonneoplastic disorders of the pancreas. In Odze RD, Goldblum JR, Crawford JM eds. Surgical pathology of the GI tract, liver, biliary tract, and pancreas. Philidelphia: Saunders 2004; 673-697.

16. Lankisch PG. Enzyme treatment of exocrine pancreatic insufficiency in chronic pancreatitis. Digestion 1993; 54 (Suppl. 2); 21-29.

17. Bruno MJ, Haverkort EB, Tytgat GN, van Leeuwen DJ. Maldigestion associated with exocrine pancreatic insufficiency: implications of gastrointestinal physiology and properties of enzyme preparations for a cause-related and patient-tailored treatment. Am. J. Gastroenterol. 1995; 90; 1383-1393.

18. Dimagno MJ, Dimagno EP. Chronic pancreatitis. Curr. Opin. Gastroenterol. 2006; 22; 487-497.

19. Littlewood JM, Wolfe SP, Conway SP. Diagnosis and treatment of intestinal malabsorption in cystic fibrosis. Pediatr. Pulmonol. 2006; 41; 35-49.

20. Bayless TM, Christopher NL. Disaccharidase deficiency. Am. J. Clin. Nutr. 1969; 22; 181-190.

21. Montalto M, Curigliano V, Santoro L et al. Management and treatment of lactose malabsorption. World J. Gastroenterol. 2006; 12; 187-191.

22. Troelsen JT. Adult-type hypolactasia and regulation of lactase expression. Biochim. Biophys. Acta 2005; 1723; 19-32.

23. Auricchio S. Genetically determeined disaccharidase deficiencies. In Walker WA, Durie PR, Hamilton JR et al. eds Pediatric gastrointestinal disease. Philadelphia and Toronto: Decker 1991; 647.

24. Wang Y, Harvey CB, Hollox EJ et al. The genetically programmed down-regulation of lactase in children. Gastroenterology 1998; 114; 1230-1236.

25. Robayo-Torres CC, Quezada-Calvillo R, Nichols BL. Disaccharide digestion: clinical and molecular aspects. Clin. Gastroenterol. Hepatol. 2006; 4; 276-287.

26. Maiuri L, Rossi M, Raia V, Paparo F, Garipoli V, Aurrichio S. Surface staining on the villus of lactase protein and lactase activity in adult-type hypolactasia. Gastroenterology 1993; 105; 708-714.

27. Day DW, Jass JR, Price AB et al. Morson and Dawson's gastrointestinal pathology. Malden, MA: Blackwell 2003.

28. Farrell RJ, Kelly CP. Celiac sprue. N. Engl. J. Med. 2002; 346; $180-188$.

29. Chand N, Anastasios AM. Celiac disease: current concepts in diagnosis and treatment. J. Clin. Gastroenterol. 2006; 40; 3-14.

30. Holdstock G, Eade DE, Isaacson P, Smith CL. Endoscopic duodenal biopsy in celiac disease and duodenitis. Scand. J. Gastroenterol. 1979; 14; 717-720.

31. Collin P. New diagnostic findings in celiac disease. Ann. Med. 1999; 31; 399-405.

32. Antonioli DA. Celiac disease: a progress report. Mod. Pathol. 2003; 16; 342-346. 
33. Baer AX, Bayless TM, Yardley JH. Intestinal ulceration and malabsorption syndromes. Gastroenterology 1980; 79; 754-765.

34. Catassi C, Fabiani E. The spectrum of celiac disease in children. Baillieres Clin. Gastroenterol. 1997; 11; 485-507.

35. Corazza GR, Gasbarrini G. Coeliac disease in adults. Baillieres Clin. Gastroenterol. 1995; 9; 329-350.

36. Green PHR. The many faces of celiac disease: clinical presentation of celiac disease in the adult population. Gastroenterology 2005; 128; S74-S78.

37. Fasano A, Catassi C. Current approaches to diagnosis and treatment of celiac disease: an evolving spectrum. Gastroenterology 2001; 120; 636-651.

38. Farstad IN, Johansen F-E, Vlatkovic L et al. Heterogeneity of intraepithelial lymphocytes in refractory sprue: potential implications of CD30 expression. Gut 2002; 51; 372-378.

39. Mahadeva S, Wyatt JI, Howdle PD. Is a raised intraepithelial lymphocyte count with normal duodenal villous architecture clinically relevant? J. Clin. Pathol. 2002; 55; 424-428.

40. Goldstein NS. Proximal small-bowel mucosal villous intraepithelial lymphocytes. Histopathology 2004; 44; 199-205.

41. Chang F, Mahadeva U, Deere H. Pathological and clinical significance of increased intraepithelial lymphocytes (IELs) in small bowel mucosa. APMIS 2005; 113; 385-399.

42. Kakar S, Nehra V, Murray JA, Dayharsh GA, Burgart LJ. Significance of intraepithelial lymphocytosis in small bowel biopsy samples with normal mucosal architecture. Am. J. Gastroenterol. 2003; 98; 2027-2033.

43. Rubin CE, Brandborg LL, Phelps PC, Taylor HC Jr. Studies of celiac disease. I. The apparent identical and specific nature of the duodenal and proximal jejunal lesion in celiac disease and idiopathic sprue. Gastroenterology 1968; 54 (Suppl.); 800802.

44. Oberhuber G. Histopathology of celiac disease. Biomed. Pharmacother. 2000; 54; 368-372.

45. Marsh MN. Gluten, major histocompatibility complex, and the small intestine. A molecular and immunobiologic approach to the spectrum of gluten sensitivity ('celiac sprue'). Gastroenterology 1992; 102; 330-354.

46. Oberhuber G, Granditsch G, Vogelsang H. The histopathology of celiac disease: time for a standardized report scheme for pathologists. Eur. J. Gastroenterol. Hepatol. 1999; 11; 11851194.

47. Ravelli A, Bolognini S, Gambarotti M, Villanacci V. Variability of histologic lesions in relation to biopsy site in glutensensitive enteropathy. Am. J. Gastroenterol. 2005; 100; $177-185$.

48. Oberhuber G, Bodingbauer M, Mosberger I, Stolte M, Vogelsang H. High proportion of granzyme B-positive (activated) intraepithelial and lamina propria lymphocytes in lymphocytic gastritis. Am. J. Surg. Pathol. 1998; 22; 450-458.

49. Cellier C, Patey N, Mauvieux L et al. Abnormal intestinal intraepithelial lymphocytes in refractory sprue. Gatroenterology 1998; 114; 471-481.

50. Vogelsang H, Oberhuber G, Wyatt J. Lymphocytic gastritis and gastric permeability in patients with celiac disease. Gastroenterology 1996; 111; 73-77.

51. Brown I, Mino-Kenudson M, Deshpande V, Lauwers GY. Intraepithelial lymphocytosis in architecturally preserved proximal small intestinal mucosa: an increasing diagnostic problem with a wide differential diagnosis. Arch. Pathol. Lab. Med. 2006; 130; 1020-1025.

52. Schuppan D. Current concepts of celiac disease pathogenesis. Gastroenterology 2000; 119; 234-242.
53. Schuppan D, Dennis MD, Kelly CP. Celiac disease: epidemiology, pathogenesis, diagnosis, and nutritional management. Nutr. Clin. Care 2005; 8; 54-69.

54. Dieterich W, Laag E, Schopper H et al. Autoantibodies to tissue transglutaminase as predictors of celiac disease. Gastroenterology 1998; 115; 1317-1321.

55. Sulkanen S, Halttunen T, Laurila $\mathrm{K}$ et al. Tissue transglutaminase autoantibody enzyme-linked immunosorbent assay in detecting celiac disease. Gastroenterology 1998; 115; 13221328.

56. Collin P, Reunala T, Pukkala E, Laippala P, Keyrilainen O, Pasternack A. Coeliac disease-associated disorders and survival. Gut 1994; 35; 1215-1218.

57. Falchuk ZM, Gebhard RL, Sessoms C, Strober W. An in vitro model of gluten-sensitive enteropathy. Effect of gliadin on intestinal epithelial cells of patients with gluten-sensitive enteropathy in organ culture. J. Clin. Invest. 1974; 53; 487500.

58. Katz AJ, Falchuk ZM. Definitive diagnosis of gluten-sensitive enteropathy: use of an in vitro organ culture model. Gastroenterology 1978; 75; 695-700.

59. Samloff IM, David JS, Schenk EA. A clinical and histochemical study of gluten-free diet. Gastroenterology 1965; 48; 155172.

60. Yardley JH, Bayless TM, Norton JH et al. Celiac disease: a study of the jejunal epithelium before and after a gluten-free diet. N. Engl. J. Med. 1962; 267; 1173-1179.

61. Lancaster-Smith M, Packer S, Kumar PJ, Harries JT. Cellular infiltrate of the jejunum after re-introduction of dietary gluten in children with treated celiac disease. J. Clin. Pathol. 1976; 29; 587-591.

62. Sollid LM, Lie BA. Celiac disease genetics: current concepts and practical applications. Clin. Gastroenterol. Hepatol. 1999; 11; 1185-1194.

63. MacDonald WC, Dobbins WO 3rd, Rubin CE. Studies of the familial nature of celiac sprue using biopsy of the small intestine. N. Engl. J. Med. 1965; 272; 448-456.

64. Hogberg L, Falth-Magnusson K, Grodzinsky E, Stenhammar L. Familial prevalence of celiac disease: a twenty-year follow-up study. Scand. J. Gastroenterol. 2003; 1; 61-65.

65. Stenhammar L, Brandt A, Wagermark J. A family study of celiac disease. Acta Paediatr. Scand. 1982; 71; 625-628.

66. Molberg O, Mcadam SN, Korner R. et al. Tissue transglutaminase selectively modifies gliadin peptides that are recognized by gut-derived T cells in celiac disease. Nat. Med. 1998; 4; 713717.

67. Lawler M, Humphries P, O'Farrelly C et al. Adenovirus E1A gene detection by polymerase chain reaction in both the normal and celiac duodenum. Gut 1994; 35; 1226-1232.

68. Weinstein WM, Saunders DR, Tytgat GN et al. Collagenous sprue-an unrecognized type of malabsorption. N. Engl. J. Med. 1970; 283; 1297-1301.

69. Daum S, Cellier C, Mulder CJJ. Refractory celiac disease. Best Prac. Res. Clin. Gastroenterol. 2005; 19; 413-424.

70. Ryan BM, Kelleher D. Refractory celiac disease. Gastroenterology 2000; 119; 243-251.

71. Catassi C, Ratsch I-M, Fabian E et al. Coeliac disease in the year 2000: exploring the iceberg. Lancet 1994; 343; 200-203.

72. Swinson CM, Slavin G, Coles EC, Booth CC. Coeliac disease and malignancy. Lancet 1983; 1; 111-115.

73. Catassi C, Bearzi I, Holmes GKT. Association of celiac disease and intestinal lymphomas and other cancers. Gastroenterology 2005; 128; S79-S86. 
74. Smedby KE, Akerman M, Hildebrand H, Glimelius B, Ekbom A, Askling J. Malignant lymphomas in celiac disease: evidence of increased risks for lymphoma types other than enteropathytype T cell lymphoma. Gut 2005; 54; 54-59.

75. Cellier C, Delabesse E, Helmer C et al. Refractory sprue, celiac dieases, and enteropathy-associated T-cell lymphoma. Lancet 2000; 356; 203-208.

76. Gebhard RL, Falchuk ZH, Katz SL, Sessoms C, Rogentine GN, Strober W. Dermatitis herpetiformis. Immunological concomitants of small intestinal diseases and the relationship to histocompatibility antigens. J. Clin. Invest. 1974; 54; 98-103.

77. Weinstein WM. Latent celiac sprue. Gastroenterology 1974; 66; 489.

78. Unsworth DJ, Leonard NL, Fry L. Antireticulin and antigliadin antibodies in dermatitis herpetiformis and celiac disease. In Beutner EH, Chorzelski TC, Kumar V eds, Chapter 25. Immunopathology of the skin, 3rd edn. New York: John Wiley \& Sons Inc. 1987.

79. Marks J, Birkell D, Shuster S, Roberts DF. Small intestinal mucosal abnormalities in relatives of patients with dermatitis herpetiformis. Gut 1970; 11; 493-497.

80. Scott BB, Young S, Rajals SM, Marks J, Losowsky MS. Coeliac disease and dermatitis herpetiformis: further studies on their relatonship. Gut 1976; 17; 759-762.

81. Loft DE, Nwokolo CU, Ciclitira PJ. The diagnosis of gluten sensitivity and celiac disease- the two are not mutually inclusive. Eur. J. Gastroenterol. Hepatol. 1998; 10; 911-913.

82. Baker SJ, Mathan VI. Syndrome of tropical sprue in India. Am. J. Clin. Nutr. 1968; 21; 984-993.

83. Schenk EA, Samloff IM, Klipstein FA. Morphologic characteristics of jejunal biopsy in celiac disease and tropical sprue. Am. J. Pathol. 1965; 47; 765-781.

84. Swanson VL, Thomassen RW. Pathology of the jejunal mucosa in tropical sprue. Am. J. Pathol. 1965; 46; 511-551.

85. Wheby MS, Swanson VL, Bayless TM. Comparison of the ileal and jejunal biopsies in tropical sprue. Am. J. Clin. Nutr. 1971; 24; 117-123.

86. Robert ME. Inflammatory disorders of the small intestine. In Odze RD, Goldblum JR, Crawford JM eds. Surgical pathology of the GI tract, liver, biliary tract, and pancreas. Philidelphia: Saunders 2004; 177-212.

87. Cook GC. Aetiology and pathogenesis of postinfective tropical malabsorption (tropical sprue). Lancet 1984; 1; 721-723.

88. Cook GC. Postinfective malabsorption (includes tropical sprue). In Bouchier AD, Alan RN, Hodgson JF, Deighley MRB eds. Gastroenterology. Clinical practice and science. Philadelphia: Saunders 1993; 522-537.

89. Walker MM. What is tropical sprue? J. Gastroenterol. Hepatol. 2003; 18; 887-890.

90. Ghoshal UC, Ghoshal U, Ayyagari A et al. Tropical sprue is associated with contamination of small bowel with aerobic bacteria and reversible prolongation of orocecal transit time. J. Gastroenterol. Hepatol. 2003; 18; 540-547.

91. Cook GC. 'Tropical sprue': some early investigators favoured an infective cause, but was a coccidian protozoan involved? Gut 1996; 39; 428-429.

92. Daum S, Sahi E, Jansen A et al. Adult autoimmune enteropathy treated successfully with tacrolimus. Digestion 2003; 68; 86-90.

93. Leon F, Olivencia P, Rodriguez-Pena R et al. Clinical and immunological features of adult-onset generalized autoimmune gut disorder. Am. J. Gastroenterol. 2005; 99; 1563-1571.

94. Russo PA, Brochu P, Seidman EG, Roy CC. Autoimmune enteropathy. Pediatr. Dev. Pathol. 1999; 2; 65-71.
95. Bacchetta R., Passerini L, Gambineri E et al. Defective regulatory and effector $\mathrm{T}$ cell functions in patients with FOXP3 mutations. J. Clin. Invest. 2006; 116; 1713-1722.

96. Le Bras S, Geha RS. IPEX and the role of FOXP3 in the developtment and function of human Tregs. J. Clin. Invest. 2006; 116; 1473-1475.

97. Ruemmele FM, Brousse N, Goulet O. Autoimmune enteropathy: molecular concepts. Curr. Opin. Gastroenterol. 2004; 20; 587-591.

98. Moore L, Xu X, Davidson G et al. Autoimmune enteropathy with anti-goblet cell antibodies. Hum. Pathol. 1995; 26; 1162-1168.

99. Hori K, Fukuda Y, Tomita $\mathrm{T}$ et al. Intestinal goblet cell autoantibody associated enteropathy. J. Clin. Pathol. 2003; 56; 629-630.

100. Waldmann TA, Steinfeld JL, Dutcher TF et al. The role of the gastrointestinal system in 'idiopathic hypoproteinemia. Gastroenterology 1961; 41; 197-207.

101. Waldmann TA. Protein-losing enteropathy. Gastroenterology 1966; 50; 422-443.

102. Abramowsky C, Hupertz V, Kilbridge P et al. Intestinal lymphangiectasia in children: a study of upper gastrointestinal endoscopic biopsies. Pediatr. Pathol. 1989; 9; 289-297.

103. Van Tilburg AJ, van Blankenstein M, Verschoor L. Intestinal lymphangiectasia in systemic sclerosis. Am. J. Gastroenterol. 1988; 83; 1417-1419.

104. Mak K-L, Hui P-K, Chan W-Y et al. Mucosal lymphangiectasia in gastric adenocarcinoma. Arch. Pathol. Lab. Med. 1996; 120; 78-80.

105. Heresback D, Raoul J-L, Genetet N et al. Immunological study in primary intestinal lymphangiectasia. Digestion 1994; 55; 59-64.

106. Fuss IJ, Strober W, Cuccherini BA et al. Intestinal lymphangiectasia, a disease characterized by selective loss of naïve CD45RA lymphocytes into the gastrointestinal tract. Eur. J. Immunol. 1998; 28; 4275-4285.

107. Aoyagi K, Iida M, Yao T et al. Characteristic endoscopic features of intestinal lymphangiectasia: correlation with histological findings. Hepatogastroenterology 1997; 44; 133138.

108. Riemann JF, Schmidt H. Synopsis of endoscopic and other morphological findings in intestinal lymphangiectasia. Endoscopy 1981; 13; 60-63.

109. Persic M, Browse NL, Prpic I. Intestinal lymphangiectasia and protein losing enteropathy responding to small bowel resection. Arch. Dis. Child. 1998; 78; 194-196.

110. Mitomi H, Atari E, Uesugi H et al. Distinctive diffuse duodenitis associated with ulcerative colitis. Dig. Dis. Sci. 1997; 42; 684693.

111. Valdez R, Appelman HD, Bronner MP, Greenson JK. Diffuse duodenitis associated with ulcerative colitis. Am. J. Surg. Pathol. 2000; 24; 1407-1413.

112. Sasaki M, Okada K, Koyama S et al. Ulcerative colitis complicated by gastroduodenal lesions. J. Gastroenterol. 1996; 31; 585-589.

113. Sjogren RW. Gastrointestinal features of scleroderma. Curr. Opin. Rheumatol. 1996; 8; 569-575.

114. Young MA, Rose S, Reynolds JC. Gastrointestinal manifestations of scleroderma. Rheum. Dis. Clin. North Am. 1996; 22; 797-823.

115. Sjogren RW. Gastrointestinal motility disorders in scleroderma. Arthritis Rheum. 1994; 37; 1265-1282.

116. Ament ME, Shimoda SS, Saunders DP, Rubin CE. Pathogenesis of steatorrhea in three cases of small intestinal stasis syndrome. Gastroenterology 1972; 63; 728-747. 
117. Gianella RA, Rout WR, Toskes PP. Jejunal brush border injury and impaired sugar and amino acid uptake in the blind-loop syndrome. Gastroenterology 1974; 67; 965-974.

118. Goldstein F. Mechanisms of malabsorption and malnutrition in the blind-loop syndrome. Gastroenterology 1971; 61; 780784.

119. Kaye SA, Lim SG, Taylor M, Patel S, Gillespie S, Black CM. Small bowel bacterial overgrowth in systemic sclerosis: detection using direct and indirect methods and treatment outcome. Br. J. Rheumatol. 1995; 34; 265-269.

120. Krishnamurthy S, Schuffler MD. Pathology of neuromuscular disorders of the small intestine and colon. Gastroenterology 1987; 93; 610-639.

121. Schuffler MD, Beegle RG. Progressive systemic sclerosis of the gastrointestinal tract and hereditary hollow visceral myopathy: two distinguishable disorders of intestinal smooth muscle. Gastroenterology 1979; 77; 664-671.

122. Ament ME, Ochs HD, Davis SD. Structure and function of the gastrointestinal tract in primary immunodeficiency syndromes: a study of 39 patients. Medicine 1973; 52; 227-248.

123. Ament ME. Immunodeficiency syndromes and the gut. Scand. J. Gastroenterol. Suppl. 1985; 114; 127-135.

124. Ament ME, Rubin CE. Relation of giardiasis to abnormal intestinal structure and function in gastrointestinal immunodeficiency syndromes. Gastroenterology 1972; 62; 216226.

125. Kagnoff MF. Immunology and inflammation of the gastrointestinal tract. In Sleisinger MH, Fordtran JS eds. Gastrointestinal disease, 5th edn. Philadelphia: Saunders 1993; 45-86.

126. Nagura H, Kohler PF, Brown WR. Immunocytochemical characterization of the lymphocytes in nodular lymphoid hyperplasia of the bowel. Lab. Invest 1979; 40; 66-73.

127. Tytgat GN, Huibregtse K, Schellekens PTA, Feltkamp-Vroom TH. Clinical and immunologic observations in a patient with late onset immunodeficiency. Gastroenterology 1979; 76; 1458-1465.

128. Yardley JH, Hendrix TR. Immunologic status in patients with giardiasis. Gastroenterology 1980; 78; 421-422.

129. Cunningham-Rundles C. Clinical and immunologic analysis of 103 patients with common variable immunodeficiency. J. Clin. Immunol. 1989; 9; 22-33.

130. Gillin JS, Shike M, Alcock N et al. Malabsorption and mucosal abnormalities of the small intestine in the acquired immunodeficiency syndrome. Ann. Intern. Med. 1985; 102; 619-622.

131. Kotler D, Gaetz H, Lange M, Klein EB, Holt PR. Enteropathy associated with the acquired immunodeficiency syndrome. Ann. Intern. Med. 1984; 101; 421-428.

132. Kotler DP. Human immunodeficiency virus-related wasting: malabsorption syndromes. Semin. Oncol. 1998; 25 (2 Suppl. 6); $70-75$.

133. Greenson JK, Belitsos PC, Yardley JH, Bartlett JG. AIDS enteropathy: occult enteric infections and duodenal mucosal alterations in chronic diarrhea. Ann. Intern. Med. 1991; 114; 366-372.

134. Laughon BE, Druckman DA, Vernon A et al. Prevalence of enteric pathogens in homosexual men with and without acquired immunodeficiency syndrome. Gastroenterology 1988; 94; 984-993.

135. Smith PD, Lane HC, Gill VJ et al. Intestinal infection in patients with the acquired immunodeficiency syndrome (AIDS): etiology and response to therapy. Ann. Intern. Med. 1988; 108; $433-438$.
136. Kotler DP, Orenstein JM. Chronic diarrhea and malabsorption associated with enteropathogenic bacterial infection in a patient with AIDS. Ann. Intern. Med. 1993; 119; 127-128.

137. Eeftinck-Schattenkerk JK, van Gool T, van Ketal RJ et al. Clinical significance of small-intestinal microsporidiosis in HIV1-infected individuals. Lancet 1991; 337; 895-898.

138. Yan Z, Nguyen S, Poles M, Melamed J, Scholes JV. Adenovirus colitis in human immunodeficiency virus infection: an underdiagnosed entity. Am. J. Surg. Pathol. 1998; 22; 1101-1106.

139. Ukarapol N, Chartapisak W, Lertprasertsuk N et al. Cytomegalovirus-associated manifestation involving the digestive tract in children with human immunodeficiency virus infection. J. Pediatr. Gastroenterol. Nutr. 2002; 35; 669-673.

140. Batman PA, Miller ARO, Forster SM, Harris JRW, Pinching AJ, Griffin GE. Jejunal enteropathy associated with human immunodeficiency virus infection: quantitiative histology. J. Clin. Pathol. 1989; 42; 275-281.

141. Cummins AG, Labrooy JT, Stanley DP, Rowland R, Shearman DJC. Quantitative histological study of enteropathy associated with HIV infection. Gut 1990; 31; 317-321.

142. Miller AR, Griffin GE, Batman $\mathrm{P}$ et al. Jejunal mucosal architecture and fat absorption in male homosexuals infected with human immunodeficiency virus. Q. J. Med. 1988; 69; 1009-1019.

143. Kapembwa MS, Batman PA, Fleming SC, Griffin GE. HIV enteropathy. Lancet 1989; 2; 1521-1522.

144. Batman PA, Kapembwa MS, Griffin GE. Enteropathy associated with HIV. Gut 1990; 31; 960.

145. Rotterdam H, Sommers SC. Alimentary tract biopsy lesions in the acquired immune deficiency syndrome. Pathology 1985; 17; 181-192.

146. Budhraja M, Levendoglu H, Kocka F, Mangkomkanok M, Sherer R. Duodenal mucosal T cell subpopulation and bacterial cultures in acquired immune deficiency syndrome. Am. J. Gastroenterol. 1987; 82; 427-431.

147. Ellakany S, Whiteside TL, Schade RR, van Thiel DH. Analysis of intestinal lymphocyte subpopulations in patients with acquired immunodeficiency syndrome (AIDS) and AIDS-related complex. Am. J. Clin. Pathol. 1987; 87; 356-364.

148. Rodgers VD, Fassett R, Kagnoff MF. Abnormalities in intestinal mucosal $\mathrm{T}$ cells in homosexual populations including those with the lymphadenopathy syndrome and acquired immunodeficiency syndrome. Gastroenterology 1986; 90; 552-558.

149. Rodgers VD, Kagnoff MF. Abnormalities of the intestinal immune system in AIDS. Gastroenterol. Clin. North Am. 1988; $17 ; 487-494$.

150. Weber JR, Dobbins WO 3rd. The intestinal and rectal epithelial lymphocyte in AIDS: an electron-microscopic study. Am. J. Surg. Pathol. 1986; 10; 627-639.

151. Snijders F, Heenan J, van den Blink B, van Deventer SJ, ten Kate FJ. Duodenal intraepithelial and lamina propria $\mathrm{T}$ lymphocytes in human immunodeficiency virus-infected patients with and without diarrhoea. Scand. J. Gastroenterol. 1996; 31; 1176-1181.

152. Guadalupe M, Reay E, Sandaran S et al. Severe CD4+ T-cell depletion in gut lymphoid tissue during primary human immunodeficiency virus type 1 infection and substantial delay in restoration following highly active antiretroviral therapy. J. Virol. 2003; 77; 11709-11717.

153. Harriman GR, Smith PD, Horne MK et al. Vitamin B12 malabsorption in patients with acquired immunodeficiency syndrome. Arch. Intern. Med. 1989; 149; 2039-2041. 
154. Herzlich BC, Schiano TD. Reversal of apparent AIDS dementia complex following treatment with vitamin B12. J. Intern. Med. 1993; 233; 495-497.

155. Dworkin BM. Selenium deficiency in HIV infection and the acquired immunodeficiency syndrome (AIDS). Chem. Biol. Interact. 1994; 91; 181-186.

156. Ehrenpreis ED, Carlson SJ, Boorstein HL, Craig RM. Malabsorption and deficiency if vitamin B12 in HIV-infected patients with chronic diarrhea. Dig. Dis. Sci. 1994; 31; 2159-2162.

157. Taylor C, Hodgson K, Sharpstone D et al. The prevalence and severity of intestinal disaccharidase deficiency in human immunodeficiency virus-infected subjects. Scand. J. Gastroenterol. 2000; 35; 599-606.

158. Fox CH, Kotler D, Tierney A, Wilson CS, Fauci AS. Detection of HIV-1 RNA in the lamina propria of patients with AIDS and gastrointestinal disease. J. Infect. Dis. 1989; 159; 467471.

159. Jarry A, Cortez A, Rene E, Muzeau F, Brousse N. Infected cells and immune cells in the gastrointestinal tract of AIDS patients: an immunohistochemical study of 127 cases. Histopathology 1990; 16; 133-140.

160. Modigliani R, Bodes C, Charpentier YL et al. Diarrhoea and malabsorption in acquired immune deficiency syndrome: a study of four cases with special emphasis on opportunistic protozoan infestations. Gut 1985; 26; 179-187.

161. Ullrich R, Zeitz M, Heise W, L'age M, Hoffken G, Riecken EO. Small intestinal structure and function in patients infected with human immunodeficiency virus (HIV): evidence for HIV-induced enteropathy. Ann. Intern. Med. 1989; 111; 1521.

162. Zeitz M, Ullrich R, Schneider T, Kewenig S, Hohloch K, Riecken EO. HIV / SIV enteropathy. Ann. NY Acad. Sci. 1998; 859; 139148.

163. Nannini EC, Okhuysen PC. HIV1 and the gut in the era of highly active antiretroviral therapy. Curr. Gastroenterol. Report 2002; 4; 392-398.

164. Quigley EMM, Quera R. Small intestinal bacterial overgrowth: roles of antibiotics, prebiotics, and probiotics. Gastroenterology 2006; 130; S78-S90.

165. Husebye E. The pathogenesis of gastrointestinal bacterial overgrowth. Chemotherapy 2006; 51 (Suppl. 1); 1-22.

166. Ghoshal U, Ghoshal UC, Ranjan P, Naik SR, Ayyagary A. Spectrum and antibiotic sensitivity of bacteria contaminating the upper gut in patients with malabsorption syndrome from the tropics. BMC Gastroenterol. 2003; 3; 9.

167. Bouhnik Y, Alain S, Attar A et al. Bacterial populations contaminating the upper gut in patients with small intestinal bacterial overgrowth syndrome. Am. J. Gastroenterol. 1999; 94; 1327-1331.

168. Mitsui T, Shimaoka K, Goto Y et al. Small bowel bacterial overgrowth is not seen in healthy adults but is in disabled older adults. Hepatogastroenterology 2006; 53; 82-85.

169. Teo M, Chung S, Chitti L et al. Small bowel bacterial overgrowth is a common cause of chronic diarrhea. J. Gastroenterol. Hepatol. 2004; 19; 904-909.

170. Haboubi NY, Lee GS, Montgomery RD. Duodenal mucosal morphometry of elderly patients with small intestinal bacterial overgrowth: response to antibiotic treatment. Age Ageing 1991; 20; 29-32.

171. Riordan SM, McIver CJ, Wakefield D, Duncombe VM, Thomas MC, Bolin TD. Small intestinal mucosal immunity and morphometry in luminal overgrowth of indigenous gut flora. Am. J. Gastroenterol. 2001; 96; 494-500.
172. Jonas A, Krishnan C, Forstner G. Pathogenesis of mucosal injury in the blind loop syndrome. Gastroenterology 1978; 75; 791-795.

173. Toskes PP, Giannella RA, Jervis HR, Rout WR, Takeuchi A. Small intestinal mucosal injury in the experimental blind loop syndrome. Light- and electron-microscopic and histochemical studies. Gastroenterology 1975; 68; 1193-1203.

174. Mathias JR, Clench MH. Review: pathophysiology of diarrhea caused by bacterial overgrowth of the small intestine. Am. J. Med. Sci. 1985; 289; 243-248.

175. Riordan SM, McIver CJ, Wakefield D, Duncombe VM, Bolin TD, Thomas MC. Luminal antigliadin antibodies in small intestinal bacterial overgrowth. Am. J. Gastroenterol. 1997; 92; 13351338.

176. Whipple GH. A hitherto undescribed disease characterized anatomically by deposits of fat and fatty acids in the intestinal and mesenteric lymphatic tissues. Bull. Johns Hopkins Hosp. 1907; 18; 382-391.

177. Dutly F, Altwegg M. Whipple's disease and 'Tropheryma whippelii'. Clin. Microbiol. Rev. 2001; 14; 561-583.

178. Marth T, Raoult D. Whipple's disease. Lancet 2003; 361; 239246.

179. Bai JC, Mazure RM, Vazquez H et al. Whipple's disease. Clin. Gastroenterol. Hepatol. 2004: 2; 849-860.

180. Muir-Padilla J, Myers JB. Whipple disease: a case report and review of the literature. Arch. Pathol. Lab. Med. 2005; 129; 933-936.

181. Monkemuller K, Fry LC, Rickes S, Malfertheiner P. Whipple's disease. Curr. Infect. Dis. Report 2006; 8; 96-102.

182. Raoult D, Birg ML, La Scola B et al. Cultivation of the bacillus of Whipple's disease. N. Engl. J. Med. 2000; 342; 620-625.

183. Misbah SA, Mapstone NP. Whipple's disease revisited. J. Clin. Pathol. 2000; 53; 750-755.

184. Misbah SA, Aslam A, Costello C. Whipple's disease. Lancet 2004; 363; 654-656.

185. Bassotti G, Pelli MA, Ribacchi R. et al. Giardia lamblia infestation reveals underlying Whipple's disease in a patient with longstanding constipation. Am. J. Gastroenterol. 1991; 86; 371-374.

186. Gil Ruiz JA, Gil Simon P, Aparicio Duque R, Mayor Jerez JL. Association between Whipple's disease and Giardia lamblia infection. Rev. Esp. Enferm. Dig. 2005; 97; 521-526.

187. Desnues B, Ihrig M, Raoult D, Mege J-L. Whipple's disease: a macrophage disease. Clin. Vaccine Immunol. 2006; 13; 170178.

188. Kuhajda FP, Belitsos NJ, Keren DF, Hutchins GM. A submucosal variant of Whipple's disease. Gastroenterology 1982; 82; $46-50$.

189. Gillin JS, Urmacher C, West R, Shike M. Disseminated Mycobacterium avium-intercellulare infection in acquired immunodeficiency syndrome mimicking Whipple's disease. Gastroenterology 1983; 85; 1187-1191.

190. McCullough K, Damjanov I. Intestinal histoplasmosis mimicking Whipple's disease. Histopathology 2006; 48; 306-323.

191. Wolfe MS. Giardiasis. Clin. Microbiol. Rev. 1992; 5; 93-100.

192. Phillips SC, Mildvan D, William DC, Gelb AM, White MC. Sexual transmission of enteric protozoa and helminths in a venereal-disease-clinic population. N. Engl. J. Med. 1981; 305; 603-606.

193. da Silva JR, Coutinho SG, Dias LB, de Figueiredo N. Histopathologic findings in giardiasis: a biopsy study. Am. J. Dig. Dis. 1964; 10; 355-365. 
194. Sun T. The diagnosis of giardiasis. Am. J. Surg. Pathol. 1980; 4; 265-271.

195. Oberhuber G, Kastner N, Stolte M. Giardiasis: a histologic analysis of 567 cases. Scand. J. Gastroenterol. 1997; 32; 4851.

196. Levinson JD, Nastro LJ. Giardiasis with total villous atrophy. Gastroenterology 1978; 74; 271-275.

197. Current WL, Reese NC, Ernst JV, Bailey WS, Heyman MB, Weinstein WM. Human cryptosporidiosis in immunocompetent and immunodeficient persons. Studies of an outbreak and experimental transmission. N. Engl. J. Med. 1983; 308; 12521257.

198. Meisel JL, Perera DR, Meligro C, Rubin CE. Overwhelming watery diarrhea associated with Cryptosporidium in an immunocompromised patient. Gastroenterology 1978; 70; 1156-1160.

199. MacKenzie WR, Hoxie NJ, Proctor ME et al. A massive outbreak in Milwaukee of cryptosporidium infection transmitted through the public water supply. N. Engl. J. Med. 1994; 331; 161-167.

200. Chappell CL, Okhuysen PC. Cryptosporidiosis. Curr. Opin. Infect. Dis. 2002; 15; 523-527.

201. Hunter PR, Thompson RCA. The zoonotic transmission of Giardia and Cryptosporidium. Int. J. Parasitol. 2005; 35; 1181-1190.

202. Jessurun J, Pambuccian S. Infectious and inflammatory disorders of the gallbladder and extrahepatic biliary tract. In Odze RD, Goldblum JR, Crawford JM eds. Surgical pathology of the GI tract, liver, biliary tract, and pancreas. Philidelphia: Saunders 2004; 609-638.

203. Keeling PJ, Fast NM. Microsporidia: biology and evolution of highly reduced intracellular parasites. Annu. Rev. Microbiol. 2002; 56; 93-116.

204. Orenstein JM, Chiang J, Steinberg W, Smith PD, Rotterdam H, Kotler DP. Intestinal microsporidiosis as a cause of diarrhea in human immunodeficiency virus-infected patients. Hum. Pathol. 1990; 21; 475-481.

205. Asmuth DM, DeGirolami PC, Federman M et al. Clinical features of microsporidiosis in patients with AIDS. Clin. Infect. Dis. $1994 ; 18 ; 819-825$.
206. van Gool T, Hollister WS, Schattenkerk JE et al. Diagnosis of Enterocytozoon bieneusi microsporidiosis in AIDS patients by recovery of spores from faeces. Lancet 1990; 336; 697698.

207. Orenstein JM, Zierdt W, Zierdt C, Kotler DP. Identification of spores of Enteroctyozoon bieneusi in stool and duodenal fluid from AIDS patients. Lancet 1990; 336; 1127-1128.

208. Rabeneck L, Gyorkey F, Genta RM, Gyorkey P, Foote LW, Risser JM. The role of microsporidia in the pathogenesis of HIV-related chronic diarrhea. Ann. Intern. Med. 1993; 119; 895-899.

209. van Gool T, Canning EU, Gillis H, van den Bergh-Weerman MA, Eeftinck-Schattenkerk JK, Dankert J. Septata intestinalis frequently isolated from stool of AIDS patients with a new cultivation method. Parasitology 1994; 109; 281289.

210. Franzen C, Muller A. Microsporidiosis: human diseases and diagnosis. Microbes Infect. 2001; 3; 389-400.

211. Weber R, Bryan RT, Owen RL, Wilcox CM, Gorelkin L, Visvesvara GS. Improved light-microscopical detection of microsporidia spores in stool and duodenal aspirates. The Enteric Opportunistic Infections Working Group. N. Engl. J. Med. 1992; 326; 161-166.

212. Giang TT, Kotler DP, Garro ML, Orenstein JM. Tissue diagnosis of intestinal microsporidiosis using the chromotrope-2R modified trichrome stain. Arch. Pathol. Lab. Med. 1993; 117; 12491251.

213. Sobottka I, Schwartz DA, Schottelius J et al. Prevalence and clinical significance of intestinal microsporidiosis in human immunodeficiency virus-infected patients with and without diarrhea in Germany: a prospective coprodiagnostic study. Clin. Infect. Dis. 1998; 26; 475-480.

214. Orenstein JM. Diagnostic pathology of microsporidiosis. Ultrastruct. Pathol. 2003; 27; 141-149.

215. Conteas CN, Berlin OG, Ash LR, Pruthi JS. Therapy for human gastrointestinal microsporidiosis. Am. J. Trop. Med. Hyg. 2000; 63; 121-127. 